\title{
Theoretical and Experimental Approaches Aimed at Drug Design Targeting Neurodegenerative Diseases
}

\author{
Samuel Morales-Navarro ${ }^{1}$, Luis Prent-Peñaloza ${ }^{2}$, Yeray A. Rodríguez Núñez ${ }^{3}$, \\ Laura Sánchez-Aros ${ }^{4}$, Oscar Forero-Doria ${ }^{5}{ }^{\circledR}$, Wendy González ${ }^{4,6}{ }^{\circledR}$, Nuria E. Campilllo ${ }^{7}$, \\ Miguel Reyes-Parada ${ }^{8,9}$, Ana Martínez ${ }^{7}$ (D) and David Ramírez ${ }^{10, *(D)}$ \\ 1 Bachillerato en Ciencias, Facultad de Ciencias, Universidad Santo Tomás, Av. Circunvalación Poniente \#1855, \\ 3460000 Talca, Chile; smoralesn@santotomas.cl \\ 2 Organic Synthesis Laboratory and Biological Activity (LSO-Act-Bio), Doctorado en Ciencias Aplicadas, \\ Facultad de Ingeniería e Instituto de Química de Recursos Naturales, Universidad de Talca. 1 Poniente No. \\ 1141, 3460000 Talca, Chile; luisprent@gmail.com \\ 3 Departamento de Ciencias Químicas, Facultad de ciencias Exactas, Universidad Andrés Bello, Quillota 980, \\ 2531015 Viña del Mar, Chile; yenuro30@gmail.com \\ 4 Centro de Bioinformática y Simulación Molecular (CBSM), Universidad de Talca. 1 Poniente No. 1141, \\ 3460000 Talca, Chile; laura.sanchez@utalca.cl (L.S.-A.); wgonzalez@utalca.cl (W.G.) \\ 5 Instituto de Química de Recursos Naturales, Universidad de Talca. 1 Poniente No. 1141, 3460000 Talca, \\ Chile; oforero@utalca.cl \\ 6 Millennium Nucleus of Ion Channels-Associated Diseases (MiNICAD), Universidad de Talca. 1 Poniente \\ No. 1141, 3460000 Talca, Chile \\ 7 Department of Chemical and Physical Biology, Centro de Investigaciones Biológicas (CIB, CSIC) Ramiro de \\ Maeztu, 28040 Madrid, Spain; nuria.campillo@csic.es (N.E.C.); ana.martinez@csic.es (A.M.) \\ 8 Centro de Investigación Biomédica y Aplicada (CIBAP), Escuela de Medicina, Facultad de Ciencias Médicas, \\ Universidad de Santiago de Chile, Av. Libertador Bernardo O'Higgins 3677, 8900000 Santiago, Chile; \\ miguel.reyes@usach.cl or miguelreyesparada1@gmail.com \\ 9 Facultad de Ciencias de la Salud, Universidad Autónoma de Chile, Avenida Pedro de Valdivia 425 \\ 8320000 Santiago, Chile \\ 10 Instituto de Ciencias Biomédicas, Facultad de Ciencias de la Salud, Universidad Autónoma de Chile, \\ El Llano Subercaseaux 2801-Piso 5, 8200000 Santiago, Chile \\ * Correspondence: david.ramirez@uautonoma.cl; Tel.: +56-2-23036667
}

Received: 31 October 2019; Accepted: 7 December 2019; Published: 10 December 2019

check for updates

\begin{abstract}
In recent years, green chemistry has been strengthening, showing how basic and applied sciences advance globally, protecting the environment and human health. A clear example of this evolution is the synergy that now exists between theoretical and computational methods to design new drugs in the most efficient possible way, using the minimum of reagents and obtaining the maximum yield. The development of compounds with potential therapeutic activity against multiple targets associated with neurodegenerative diseases/disorders (NDD) such as Alzheimer's disease is a hot topic in medical chemistry, where different scientists from various disciplines collaborate to find safe, active, and effective drugs. NDD are a public health problem, affecting mainly the population over 60 years old. To generate significant progress in the pharmacological treatment of NDD, it is necessary to employ different experimental strategies of green chemistry, medical chemistry, and molecular biology, coupled with computational and theoretical approaches such as molecular simulations and chemoinformatics, all framed in the rational drug design targeting NDD. Here, we review how green chemistry and computational approaches have been used to develop new compounds with the potential application against NDD, as well as the challenges and new directions of the drug development multidisciplinary process.
\end{abstract}


Keywords: Green chemistry; drug design; neurodegenerative diseases; molecular modeling; medical chemistry; chemoinformatics

\section{Introduction}

A significant increase in per capita income and educational level, as well as a broad and better access to health insurance coverage plans, among other factors, has favored a considerable increase in the population lifespan [1]. However, this worldwide rise in population aging has brought a remarkable increase in the diseases associated with the elderly, being neurodegenerative diseases/disorders (NDD), the most common of them [2]. In 2010, a study conducted by the National Institutes of Health (NIH) determined that $8 \%$ of the world's population was over 65 years old, and it is expected to reach 2 billion people ( $16 \%$ of the world population) in 2050 [3]. Therefore, the development of new therapies for the treatment of diseases associated with aging has become of vital interest to improve the situation of the elderly [2].

Alzheimer's disease (AD), Parkinson's disease (PD), Huntington's disease (HD), and amyotrophic lateral sclerosis (ALS) are the most representative form of NDD [4]. NDD are characterized by a progressive functional loss of some neuronal cells, which—in most of cases-leads to an irreversible deterioration of central nervous system (CNS) functioning [5]. These diseases progress with age and have oxidative stress as a standard feature [6]. Specifically, AD and PD are the most prevalent forms of NDD among older people. AD is characterized by short-term memory loss, steady cognitive impairment, problems with language, and difficulties in carrying out basic activities such as driving or shopping [7,8]. It is estimated that population with AD in 2050 will triple the existing population [9]. $\mathrm{PD}$ is the second most common NDD, affecting $1 \%$ of the population over 60 years old, and increasing to $2-3 \%$ of the population over 65 years. It is associated with Lewy bodies, abnormal aggregates of alpha-synuclein protein, and loss of dopaminergic neurons in the substantia nigra [10]. This progressive disease is clinically characterized by motor symptoms including resting tremor, walking difficulties, and bradykinesia as well as by non-motor symptoms such as emotional disturbances [11]. HD is a rare NDD characterized by involuntary movements (called chorea), behavior modifications, and the manifestation of psychiatric symptoms [12]. ALS is a complex disorder caused by degeneration and death of motor neurons generating paralysis, muscular wasting, rigidity and atrophy, respiratory failure, among other symptoms $[4,13]$.

A common risk factor for NDD is oxidative stress which corresponds to a dysregulated production of reactive oxygen species (ROS), such as hydrogen peroxide and nitric oxide. ROS are associated with the abnormal functioning of neuronal cells. High levels of ROS lead to a disbalance of intracellular calcium, which stimulates different metabolic pathways that induce protein misfolding and/or aggregation, and the activation of apoptotic signaling cascades [6].

Unfortunately, most NDD have no cure to date. The current treatment can only relieve the symptoms, but not the etiology of the disease. AD, PD, HD, and ALS, although different disorders, share the same mechanism in the progress of neuron death [5]. Solloway et al. [14] suggest that a multitarget approach can generate a disease modification, which could be able to stop the progress of the NDD, thus allowing the regeneration of affected tissues.

Identifying new drugs with therapeutic potential for the treatment of NDD is not a simple task using conventional strategies. Classical therapies are unable to stop or slow down the neurodegenerative progression. The introduction of a new drug for the treatment of any disease showing a widespread incidence in the population is a complicated, risky, and costly process, not only concerning money but also labor, with a time of development between 10 to 14 years and a cost of around 1 trillion dollars [15]. In addition, the pharmaceutical industry faces the dilemma between reducing the impact of a disease, and improving the living quality of population and, on the other hand, the high levels of waste involved in the drug production at high scale, which might be even higher 
than those of similar industrial processes such as petrochemicals, for example [16]. In this context, green chemistry techniques are environmentally friendly, reduce cost and, in association with other "green" techniques such as in silico approaches, contribute with high efficiency to the success rate of drug development. In this review, we highlight the importance of using both, experimental and theoretical approaches such as green chemistry and molecular modeling, aimed to the rational drug design targeting NDD. Our multidisciplinary research team is working in different institutions and countries, tackling the lack of active and effective compounds against NDD, by synthesizing active molecules such as tetrahydroquinolines [17], diN-substituted glycyl-phenylalanine derivatives [18], coumarin-quinoline hybrids [19], aryl-1, 2, 3-triazolyl benzylpiperidines [20], indolylpiperidines [21], and glycogen synthase kinase-3 (GSK3) and tau-aggregation inhibitors [22], among others. These novel active molecules have been obtained by using a combination of green chemistry protocols, predictive chemoinformatics tools, and molecular modeling approaches.

\section{A Safer Approach to NDD Drug Discovery: Green Chemistry Technology}

Green chemistry comprises a group of guidelines that consist in obtaining novel eco-friendly protocols and sustainable alternatives to existing methods, which involve energy consumption and solvent-free reactions, among others [23]. Solvents are a crucial point of green chemistry since it is one of the primary sources of waste in multicomponent reactions. Multiple alternatives to reduce the use of conventional organic solvents have been generated, including the development of solvent-free reactions. Other options to replace the organic solvent are ionic liquids, polyethylene glycol polymers, and water (which is the main green solvent) [24]. Along similar lines, Lim and co-workers developed the synthesis of benzoxazoles from resin-bound esters using microwave irradiation, a well-known green chemistry technique. The synthetic strategy began with the formation of resin-bound esters, which was obtained for the reaction of wang resin $\mathbf{1}$ and different acyl chlorides $\mathbf{2}$ (Figure 1). Then the cyclocondensation of resin-bound esters 3 with aminophenols 4 promoted by microwave radiation under methanesulfonic acid as catalyst provided substituted benzoxazole derivatives 5 [25].

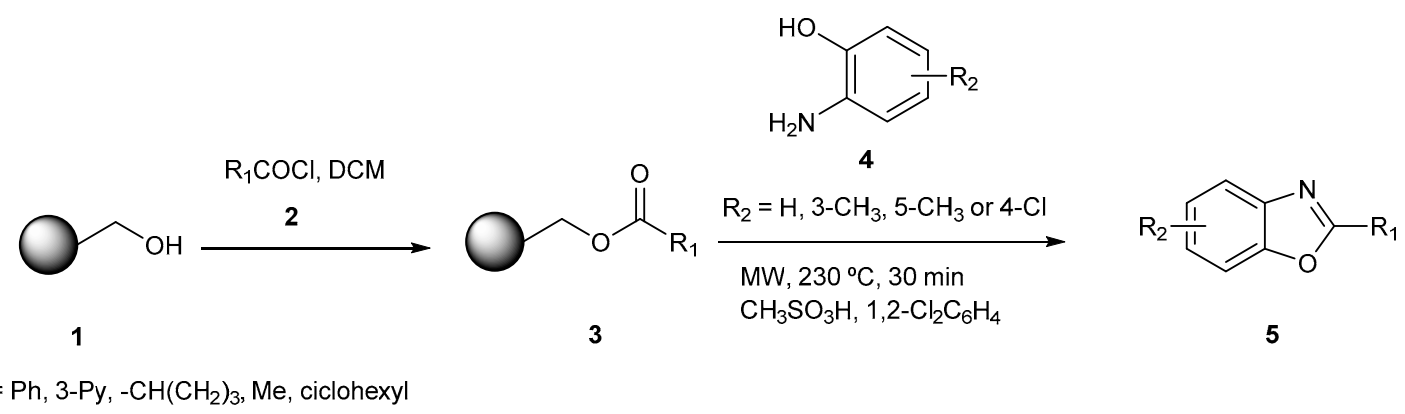

Figure 1. Solid-phase synthesis of benzoxazoles using microwave irradiation.

On the other hand, in the drug design process, the use of computational methods has been of great support due to its predictive power in terms of the biological activity of molecules based on their structural and electronic characteristics, thus reducing the cost of synthesis and biological assays. For example, the chemical space for the synthesis of inhibitors of a specific target can be confined thanks to the previous prediction [26]. The usefulness of molecular modeling has made its use more routine, thus becoming a promising tool in the development of green chemistry.

Multicomponent reactions (MCRs) are widely used in combinatorial chemistry thanks to simple set-up, high variability, and high reaction yield. Additionally, the complex chemistry architecture offered is an advantage in drug discovery [27]. In this way, a particular group of MCRs is based on the isocyanides group exemplified by Ugi and Passerini reactions or in one of their different variations [28]. Small molecules, such as benzoxazole derivatives (A $\beta$ aggregation inhibitors), have been synthesized employing the Ugi reaction [29,30]. Moreover, Spatz and co-workers [31], designed a synthetic plan to 
obtain a series of benzoxazole derivatives 11. These compounds were obtained across the Ugi product formation 10 and its subsequent cyclization promoted by CuI (10 mol \%) (Figure 2).

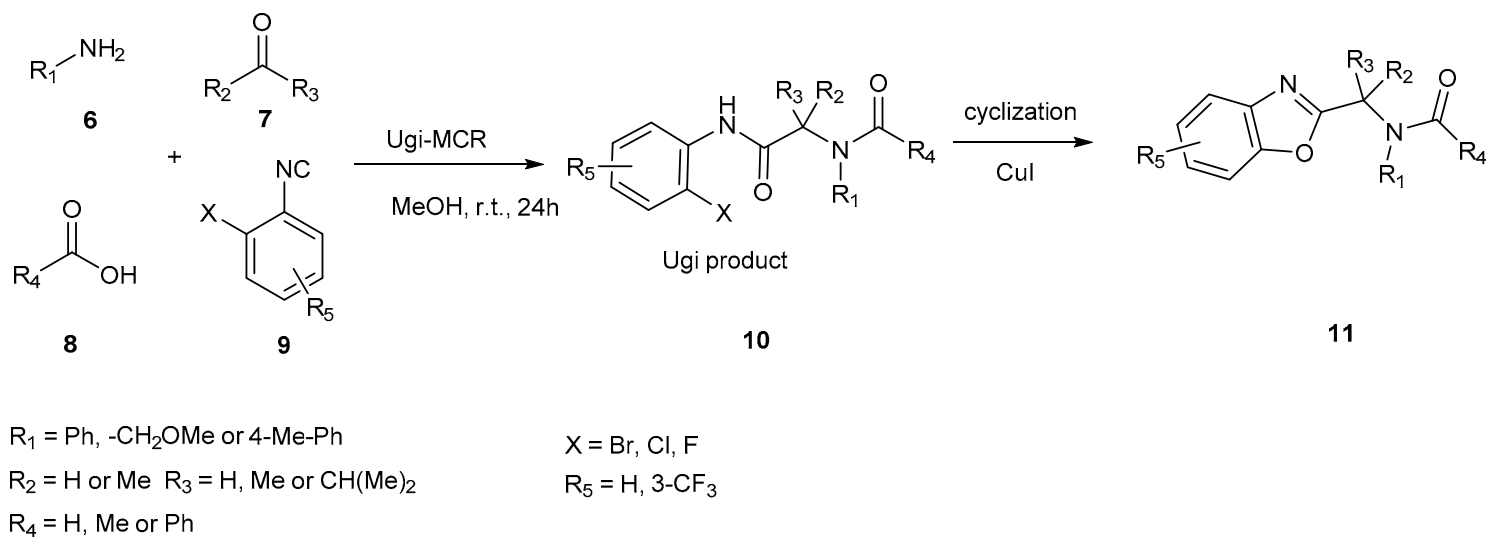

Figure 2. Ugi-MCR (multicomponent reaction) and cyclization promoted by $\mathrm{CuI}$ to get benzoxazoles derivatives highly substituted.

In general terms, MCRs allow the synthesis of complex molecules by assembling more than two starting materials in one step [32]. In this context, Jangale and Dalal developed the three-component reaction for the synthesis of a variety of (Z)-methyl 2-((Z)-2-(E-(2/3/4-substituted benzylidene) hydrazono)-4-oxo-3-phenylthiazolidin-5-ylidene)acetates 15 by greener way in ethanol with good to excellent yields (89-96\%), (Figure 3) [33].

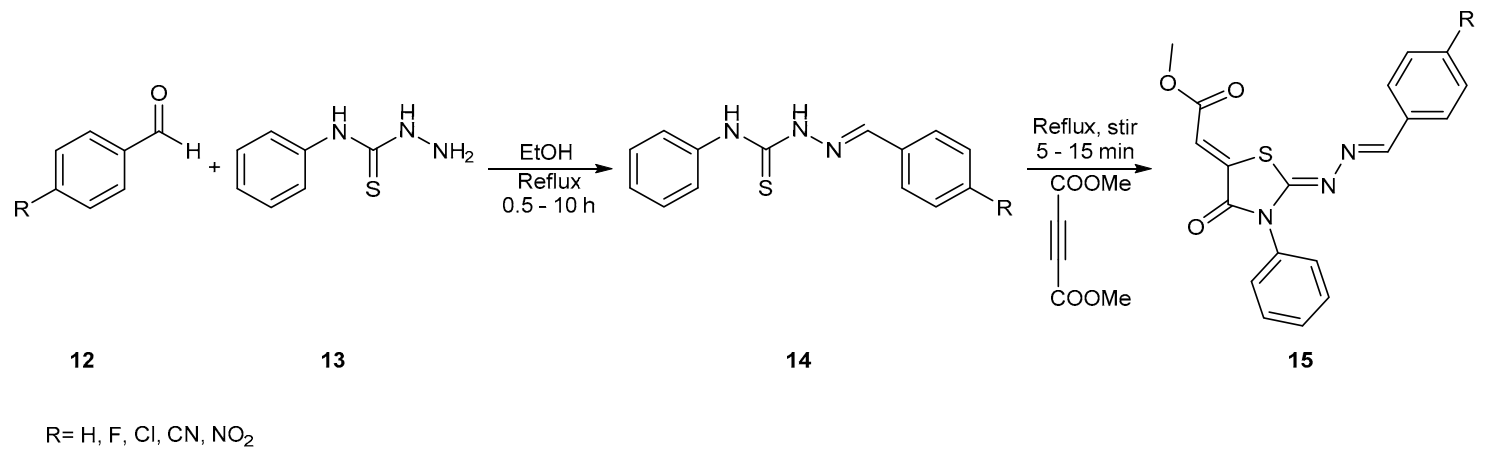

Figure 3. Catalyst-free synthesis of (Z)-methyl 2-((Z)-2-((E)-(2/3/4-substituted benzylidene) hydrazono)-4-oxo-3-phenylthiazolidin-5-ylidene) acetates.

The correct selection of starting materials is essential for designing an efficient, versatile, and eco-friendly MCR. Thus, the structural scaffold is chosen based on their reactivity, solubility, and biological properties, generating sets of compounds that increase the chemical universe available. Arylglyoxals $\mathbf{1 6}$ are a handy synthetic building block in organic synthesis. The presence of adjacent ketone and aldehyde groups in this block allows them to act as double electrophilic sites for cyclization reactions. Karamtulla and co-workers designed a catalyst-free on-water MW-assisted domino reaction for the efficient synthesis of trisubstituted 1,3-thiazole derivatives 19 (Figure 4), employing arylglyoxals 16 as the building block. For optimization of this synthetic protocol, different solvents, temperatures, and times of reaction were tested. They defined that: water, $130{ }^{\circ} \mathrm{C}$, and $15 \mathrm{~min}$ of the reaction was the ideal combination of conditions to obtain trisubstituted thiazoles 19 [34]. 
<smiles>[R]c1ccc(C(=O)C(O)O)cc1</smiles>

16<smiles>[X]C1=CC(=O)CC2CCC[C@@H]1C2</smiles><smiles>[Y]O[SbH]=[Ni]</smiles>

17<smiles>[R]C(N)=S</smiles>

18<smiles>[X]C1=C(c2sc([R])nc2-c2ccc([R])cc2)C(O)=C(O)CCCCC1</smiles>

19

$\mathrm{R}_{1}=\mathrm{H}, \mathrm{OMe}, \mathrm{NO}_{2}$

$\mathrm{R}_{2}=\mathrm{H}, \mathrm{OMe}, \mathrm{Cl}$

Figure 4. Domino Synthesis of 1,3-thiazoles.

In addition, Kushwaha and co-workers established a preliminary structure-activity relationship (SAR) and designed new pyrazoles containing benzofuran-tetrazole hybrids 21 (Figure 5). These three entities have been described as pharmacophores in compounds used as potential inhibitors of cholinergic enzymes and with the ability to reduce amyloid $\beta$ and tau dual aggregation. Thus, the new compounds were obtained through a simple metal-free and with high atomic economy MCR, based on Ugi-azide reaction with benzofuran-pyrazole aldehydes 20 previously produced. SAR analysis found that a tertbutyl group in the position R5 of the tetrazole scaffold is essential for a high activity 21 [35].<smiles>[R]c1ccc(-n2cc(C=O)c(-c3oc4ccccc4c3[R])n2)cc1</smiles>

20
$\mathrm{R}_{3} \mathrm{R}_{4} \mathrm{PhNH}_{2}, \mathrm{TMSN}_{3}, \mathrm{R}_{5} \mathrm{NC}$

$$
\mathrm{MeOH}, \mathrm{rt}
$$

$$
\mathrm{MeOH}, \mathrm{rt}
$$<smiles>[R]c1ccc(-n2cc(C(Nc3ccc([R])c([R])c3)c3nnnn3[R6])c(-c3oc4ccccc4c3[R])n2)cc1</smiles>

21

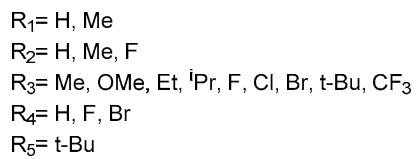

Figure 5. Synthesis of benzofuran-tetrazole derivatives.

In an attempt to design a versatile and efficient procedure for the synthesis of highly substituted indeno [1,2-b] pyrrole and acenaphtho[1,2-b] pyrrole derivatives 25 by domino three-component reaction, different variables were tested in order to optimize the reaction conditions. Ethanol (EtOH) to reflux for three hours was the ideal condition when ninhydrin 22, methyl acetoacetate 23, and tryptamine 24 react to afford a series of indene[1,2-b]pyrrole analogs 25 (Figure 6) [36]. 
<smiles>[R]C(=O)CC(C)=O</smiles>

$\mathrm{R}=\mathrm{Me}, \mathrm{OMe}, \mathrm{OEt}, \mathrm{O}^{\mathrm{t}} \mathrm{Bu}, \mathrm{O}^{\mathrm{i}} \mathrm{Pr}, \mathrm{OBn}$

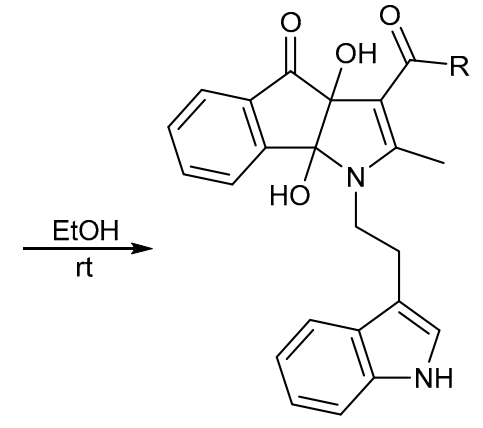

25

Figure 6. Tandem procedure for the synthesis of indeno[1,2-b] pyrrole.

Considering that $\mathrm{AD}$ is the most prevalent form of NDD, representing $60-70 \%$ of dementia cases around the world in patients over 65 years old, the search for drugs able to reduce its impact has been a subject of study for more than six decades [37]. However, as detailed above, a drug capable of curing this disease has not been discovered yet. In this context, coumarin and quinolone derivatives have been reported as potential parent scaffolds for drugs affecting different biological activities related to NDD. Duarte and co-workers reported an efficient and versatile strategy of synthesis of coumarin-quinoline hybrids 29 as inhibitors of cholinergic enzymes (Figure 7). These compounds showed high selectivity against acetylcholinesterase (AChE), and were also excellent iron chelating agents, with the most active compound against $\mathrm{AChE}$ exhibiting an $\mathrm{IC}_{50}$ of $159 \mu \mathrm{M}$. Remarkably, docking analysis (on the basis of the binding energy calculation), predicted the activity of these compounds, showing that the most active molecule of this new series had the best energy score [19].

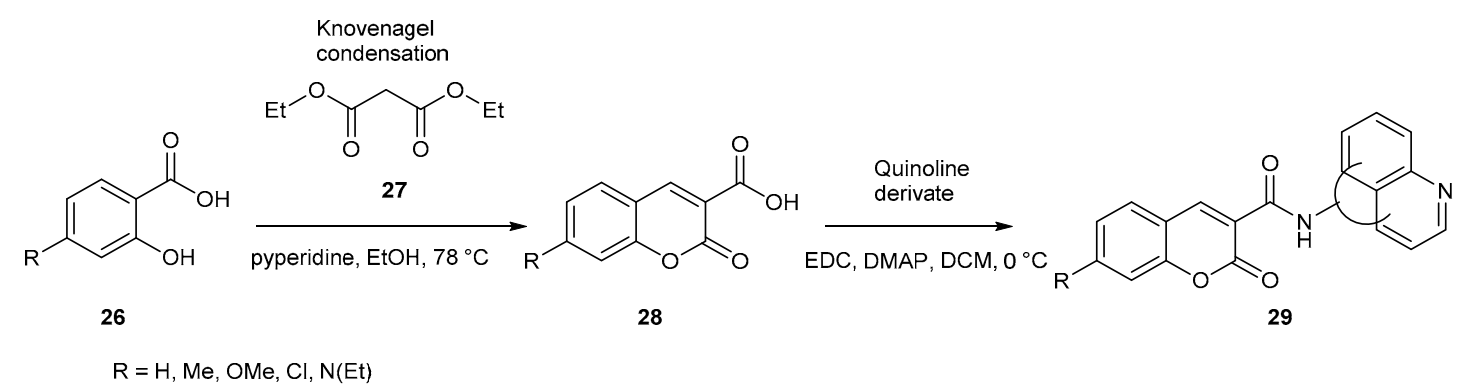

Figure 7. Synthesis of coumarin-quinoline hybrids.

Other compounds like dyhidropyrano[c]chromene derivatives have been used as cognitive enhancers in the treatment of different NDD [38]. Diverse protocols of green chemistry have been adapted to obtain this scaffold. Mehrabi and co-workers applied an efficient and useful three-component coupling of aldehydes 30, malononitrile 31, and 4-hydroxicoumarin 32 in water, using $\mathrm{CuO}$ as nanocatalyst, which resulted to be a clean reaction with high yields [39]. Similarly, Majid and co-workers carried out an scheme involving the use of morpholine as a friendly organocatalyst and water as a solvent in the one-pot synthesis of dihydropyrano[c]chromene derivatives 33 (Figure 8) [40]. 


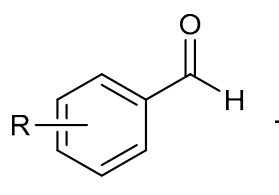

30<smiles>N#C[C+](C#N)C#N</smiles>

32<smiles>[R]c1ccc(C2C(C#N)=C(N)Oc3c2c(=O)oc2ccccc32)cc1</smiles>

33

$\mathrm{R}=\mathrm{H}, 4-\mathrm{Me}, 4-\mathrm{OMe}, 4-\mathrm{Cl}, 4-\mathrm{F}, 4-\mathrm{NO}_{2}, 3-\mathrm{NO}_{2}$

Figure 8. Synthesis of 3, 4-dihyropyrano[c]chromenes by condensation of aldehydes, 4-hydroxycoumarin and malononitrile using $\mathrm{CuO}$ nanoparticles and morpholine as catalyst.

Rodríguez and co-workers synthesized a series of allyl/propargyl tetrahydroquinoline (THQ) derivatives 37 using a simple, efficient, and mild protocol based on an acid-catalyzed three-component cationic imino Diels-Alder reaction (Figure 9). The novel compounds showed anti-AD effects (AChE and butyrylcholinesterase (BChE) inhibitory properties). Besides, a computational protocol based on docking and free energy calculations successfully predicted the binding affinity of these new ligands on AChE and BChE active sites [17].<smiles>[R]c1ccc(NCC#CCNc2ccc([R])cc2)cc1</smiles>

$\mathrm{R}=\mathrm{H}, \mathrm{Me}, \mathrm{OMe}, \mathrm{Cl}, \mathrm{Et}, \mathrm{F}, \mathrm{Br}$

Figure 9. Synthesis of $\mathrm{N}$-allyl/propargyl THQs (tetrahydroquinoline) as inhibitors of AChE (acetylcholinesterase) and BChE (butyrylcholinesterase).

The synthesis of compounds containing the 1,2,3-triazole moiety generates great interest in drug development. The best-known way to obtain it is through the Huisgen cycloaddition reaction. De Andrade and co-workers designed and synthesized a new series of 1,2,3-triazolyl benzylpiperidines 40 as BChE inhibitors through a reaction between 4-(azidomethyl)-1-benzylpiperidine 38 and different alkynes 39 under microwave-assisted click-chemistry cycloaddition reaction. Microwave heating reduces the reaction time as well as increases the yield (Figure 10). The most active compound exhibited an inhibitory activity $\left(\mathrm{IC}_{50}\right)$ of $65 \mathrm{nM}$ against $\mathrm{BChE}$ [20]. 


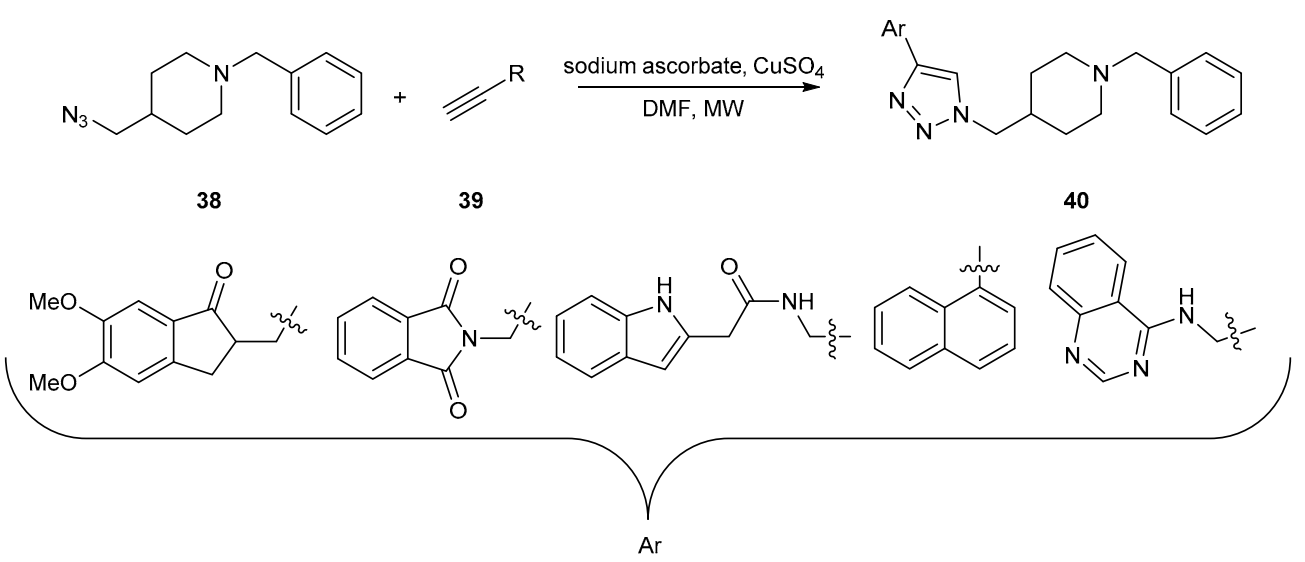

Figure 10. Synthesis of 1,2,3 triazole derivatives.

Triazole derivatives have demonstrated multiple bioactivities, such as antiinflammatory, antimicrobial, antimycotic, antimigraine, and anticancer effects [41], Besides, beta-secretase inhibition, neuroprotective capacity, and chelation properties have been reported in a new family of iminochromone carboxamides containing a triazole moiety 45 , with an $\mathrm{IC}_{50}$ value of $2.2 \mu \mathrm{M}$ for the most potent compound (Figure 11). These derivatives were constructed through a linear synthesis, starting with a cyanoacetylation $\mathbf{4 3}$ and followed by the knoevenagel condensation, which was the crucial step of the synthesis.

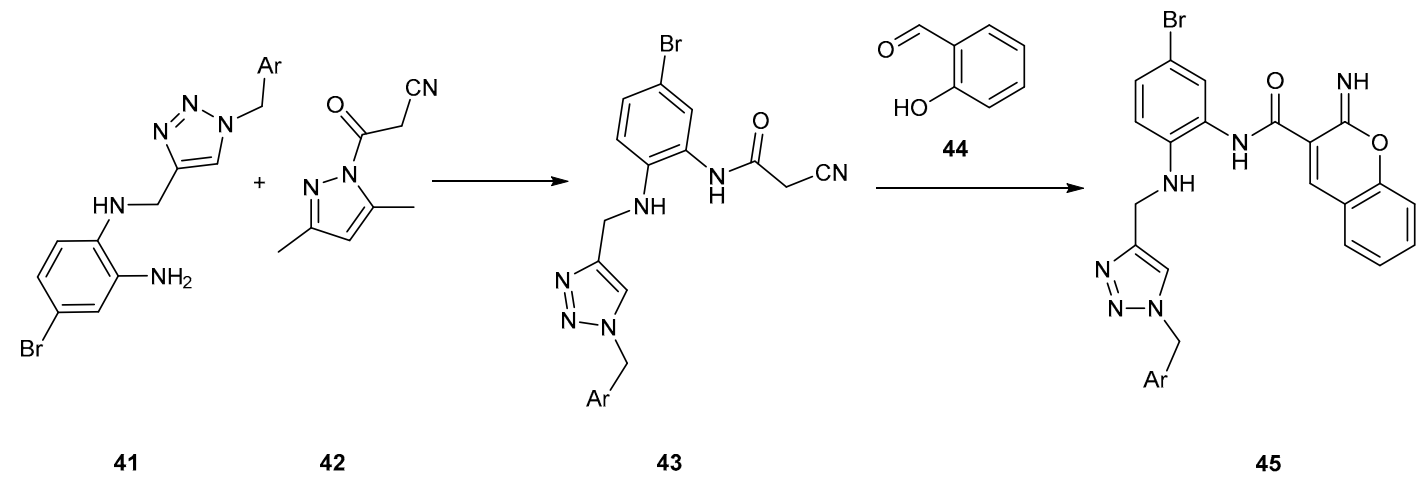

Figure 11. Synthesis of imino-2H-chromen-3-carboxamide derivatives.

Additionally, other pharmacological target in AD is the over-activation of glycogen synthase kinase (GSK-3), which is implicated in several processes associated with AD, such as tau hyperphosphorylation, and the increase of $\beta$-amyloid plaques production among others [42]. In this direction a new class of GSK-3 inhibitors containing the triazole scaffold with favorable water solubility $\mathbf{4 6 - 4 8}$ (Figure 12) were synthesized by treatment of 3-azido-2-amino-1,2,5-oxadiazole with ethyl chloroacetacetic acid, giving access to the key functionalized [1-3]-triazoles moieties [43]. 
<smiles></smiles>

46

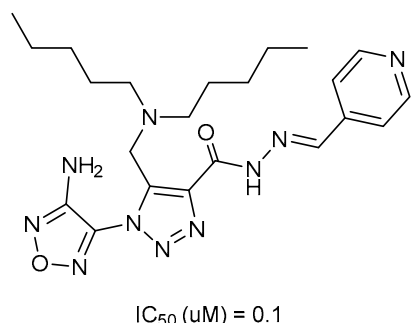

47

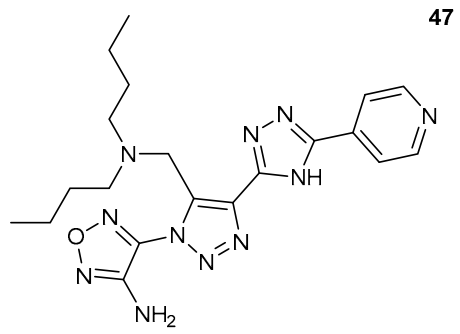

$\mathrm{IC}_{50}(\mathrm{UM})=0.24$

48

Figure 12. Inhibition of GSK-3 by Hydrazide and Triazole derivative.

Furthermore, a series of triazole-containing amino acid derivatives 52 (Figure 13) was prepared under green chemistry conditions via MCRs using lemon juice as an acidic catalyst [44]. Moreover, in silico predictions revealed that these compounds exhibited promising drug-likeness and pharmacokinetics profile.<smiles>[R7]C(=O)c1ccccc1O</smiles>

49<smiles>[R]C(N)C(=O)O</smiles>

50<smiles>NNC(N)=S</smiles>

51<smiles>[R2]C(C(=O)O)N1C(N)=NNC1([R])c1ccccc1O</smiles>

52

$\mathrm{R}_{1}=\mathrm{H}, \mathrm{Me}$

$\mathrm{R}_{2}=\mathrm{Me}, \mathrm{CH}\left(\mathrm{CH}_{3}\right)_{2}, \mathrm{CH}_{2} \mathrm{COOH}, \mathrm{CH}_{2} \mathrm{CH}_{2} \mathrm{SCH}_{3}$

Figure 13. Synthesis of 1,2,4-triazole derivatives.

In the last few years, multitarget drug design has been proposed as an alternative to address the various hypotheses (cholinergic, tau-phosphorylation, aggregation $\beta$-amyloids plaques, etc.) associated with $\mathrm{AD}$ [45]. This approach is better known as one compound multi-targets strategy [46]. Das et al. [47], synthesized and characterized dihydroactinidiolide, testing its AChE inhibitor, metal chelating, anti-aggregating (beta-amyloid plaques) activity, and cytotoxicity. Their results allow them to conclude that this molecule has a strong potential in a possible therapy against AD because it was demonstrated that it is a multitarget compound and all the analyses yielded affinity values in the nM range. Porcal et al. synthesized a set of heteroarylnitrones $\mathbf{5 4}$ (Figure 14) and tested their free radical scavenging ability as well as their neuroprotective activity. Their results showed an excellent free radical scavenging ability against different free radicals $\left({ }^{\bullet} \mathrm{OH}, \mathrm{CH}_{3}{ }^{\bullet} \mathrm{CHOH}, \mathrm{SO}_{3}{ }^{\bullet-}\right)$, and showed good neuroprotective activity without producing cell damage or cytotoxicity [48]. 


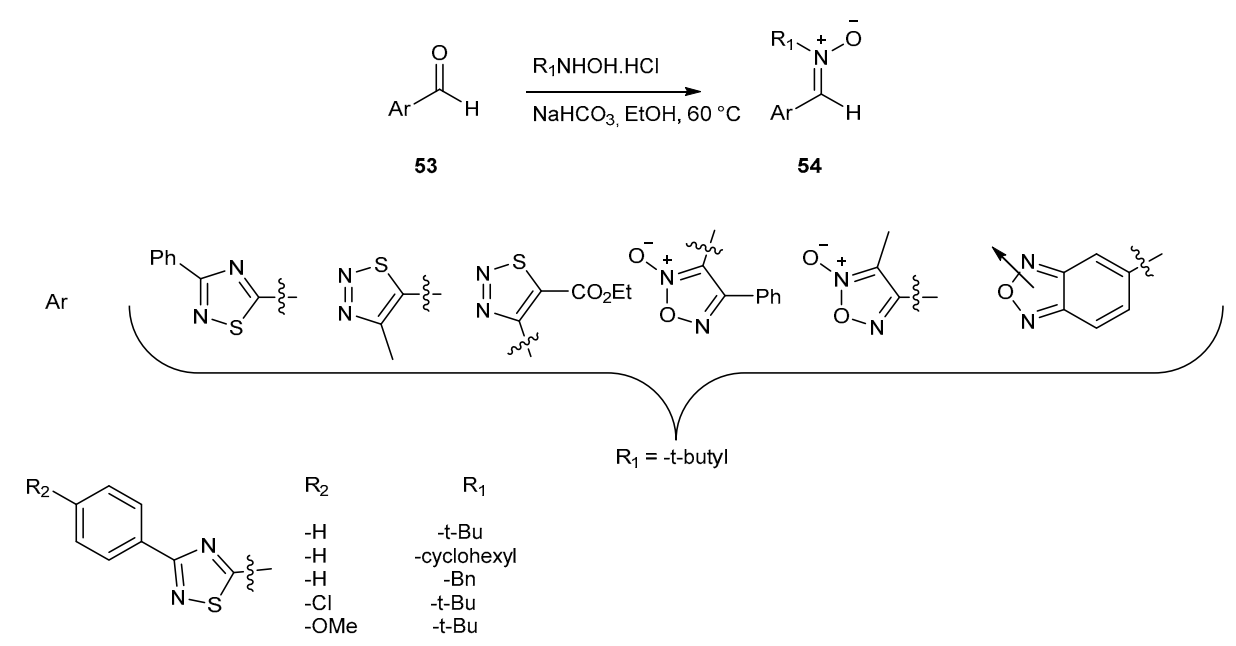

Figure 14. Synthesis of heteroarylnitrones derivatives.

Eco-friendly methods of synthesis have been applied to obtain many of these molecular scaffolds. In this sense, Gandini et al. have reported the synthesis of 2,4-thiazolidinedione (TZD) derivatives 57 (Figure 15) with the ability to inhibit both GSK 3B and the Tau protein agglomeration process, two therapeutic targets of AD. These compounds were synthesized by solvent-free microwave irradiation, mixing different aldehydes 55 with TZD 56 using an economic catalyst such as EDDA [22].

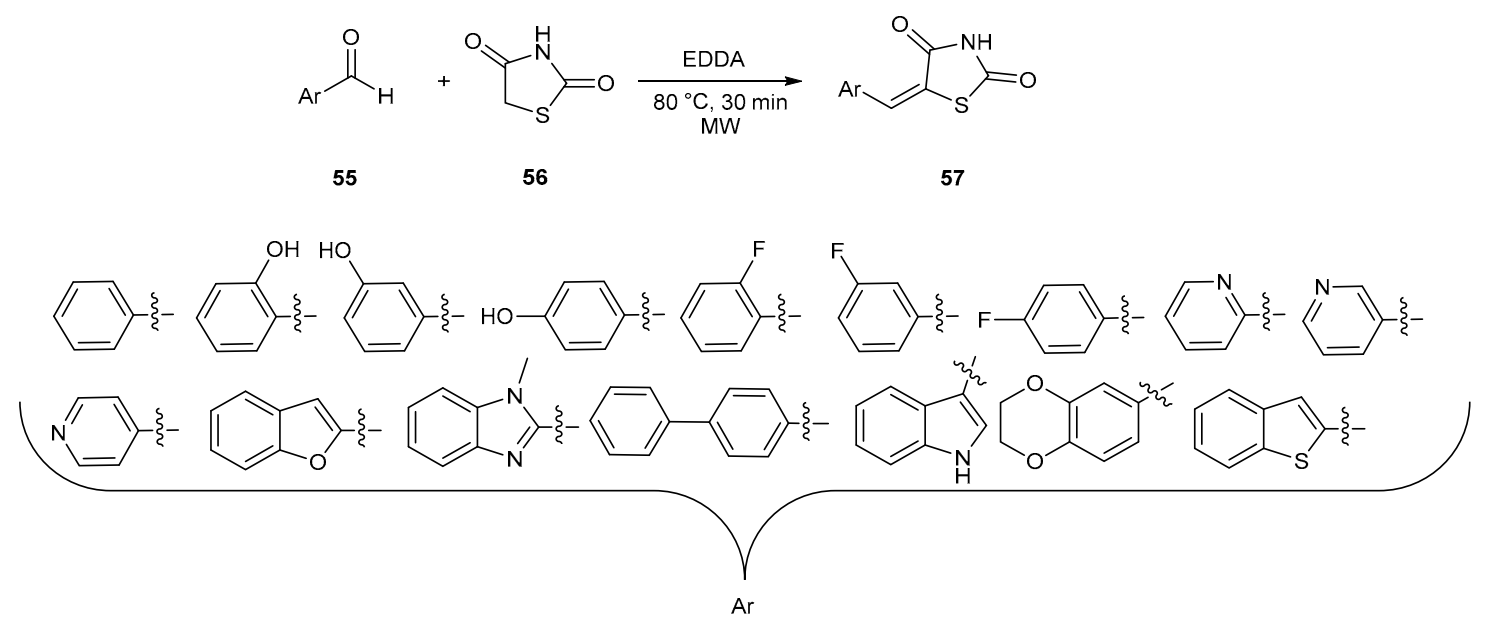

Figure 15. Synthesis of 2,4-thiazolidinedione derivatives.

The diversity of chemical descriptors, as well as the structural diversity that can be obtained from them, has been of great motivation for chemists in search of new therapeutic agents for the treatment of various diseases, including AD. In the last few decades, the use of bioinformatics and other computational tools has emerged [49]. These tools help to reduce the volume of compounds to be synthesized for a specific target, reducing the time spent in the synthesis as well as the associated costs [50]. From an environmental point of view, the use of these techniques is very important because a reduction of the number of compounds to be synthesized also reduces the number of reagents, products, and residues, optimizing the reactions and contributing to attenuate the contamination derived from the drug design process. In the next section, we will discuss the use of these tools and their benefits. 


\section{Computational Methods in Drug Design and Discovery}

In order to optimize the drug development process, reducing time-cost and increasing eco-friendly techniques to amplify the chemical space, several computational methods have arisen over the last few years to, for instance, study how a known ligand interacts with a given receptor, or to understand why a single mutation might change the binding affinity of a drug in its target. These methods are also used to design new molecules with potential improved therapeutic efficacy, and regarding approved drugs, to improve the synthesis route, and also to understand several reaction mechanisms. The use of these methods in drug discovery sciences is known as computer-aided drug design (CADD), and there are estimates that it could reduce the costs of design and drug development by over $50 \%$ [51]. Therefore, CADD is a widely used technique to reduce the cost and times associated with the discovery of drugs with desirable powerful clinical effect, high efficacy, and low side effects [52,53]. In essence, CADD methods have been classified in structure-based drug design (SBDD) and ligand-based drug design (LBDD) (Figure 16) [54]. Briefly, in the SBDD approach, the design is based on the knowledge of structural data of the molecular target, whereas in LBDD, the development of the new candidates is based on ligands with known biological activity without structural information of the target. Ligand-based approaches are potent methods based on small-molecules information using a series of known active and inactive compounds against a target. Ligand-based methods are based on finding common significant structural and physicochemical characteristics, assuming that structurally similar compounds will display similar biological activities. Conventional ligand-based techniques are quantitative structure-activity relationships (QSAR), pharmacophore-based methods, artificial neuronal networks (ANNs), and similarity searching methods. Both SBDD and LBDD approaches have in common that they allow simulating with great detail the interactions underlying the binding affinity between the therapeutic target and the recently designed compounds [55].

\section{Computer-Aided Drug Design (CADD)}

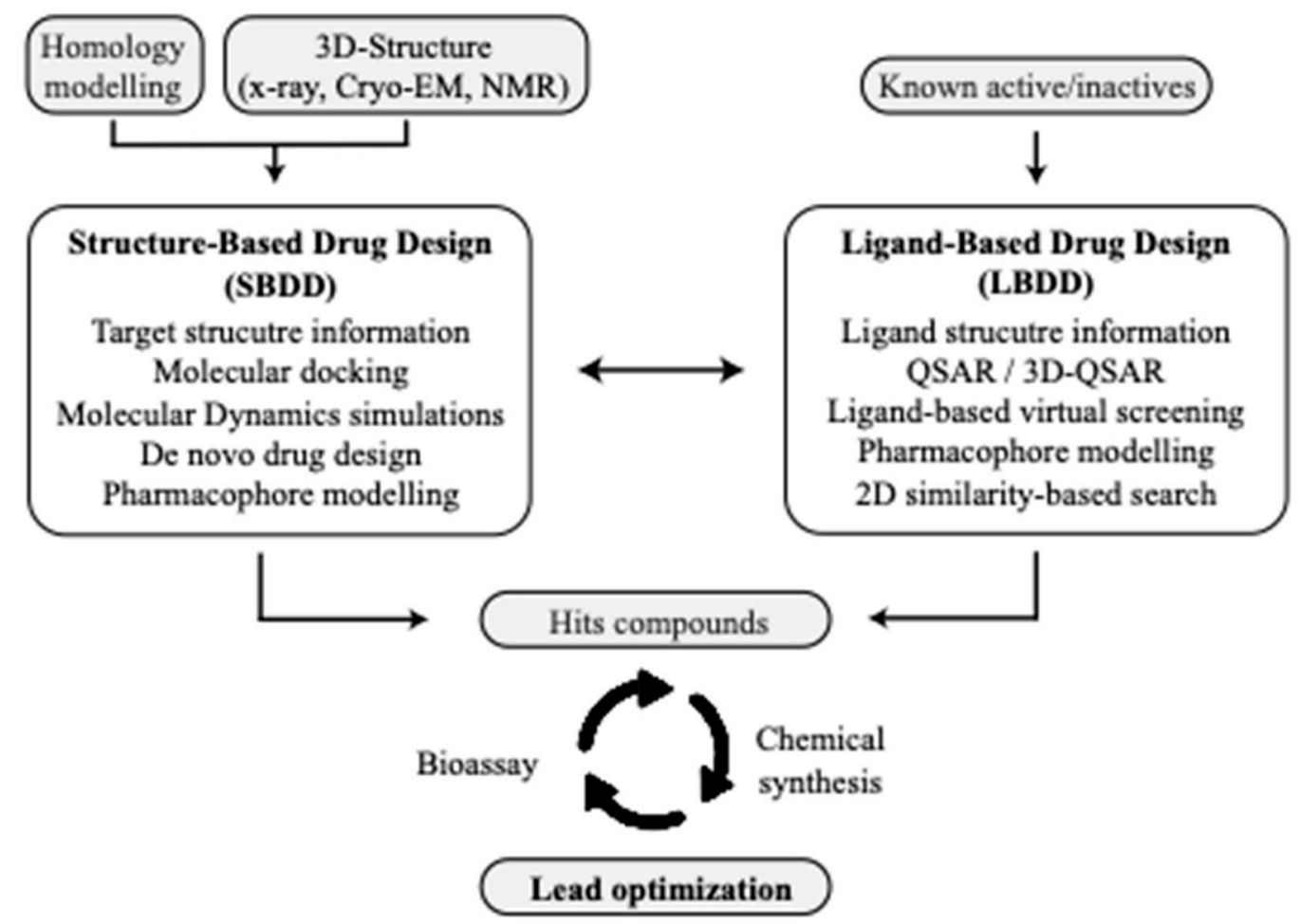

Figure 16. Traditional workflow of computer-aided drug design (CADD). 
Currently, many research groups around the world have concentrated their efforts and interest in the SBDD approaches. These are considered the most promising scientific methods to identify and develop new ligands with desirable pharmacological properties [55]. The SBDD might provide, as a result, potentially useful drugs selected on the basis of the specific binding affinities of some protein-ligand pairs. SBDD is an iterative process consisting of multiple cycles for a drug candidate before entering clinical trials. The first step includes the choice of the target which needs to be efficacious, safe, meet clinical and commercial needs, and be "druggable." This first step is especially complicated in complex diseases such as NDD. For this purpose, a target needs to be validated, and a multi-validation approach is desirable. To achieve this goal, different in silico tools could be used, such as inverse docking, molecular dynamics, QSAR, among others, as well as in vitro/in vivo techniques which through the use of both cellular and whole animal models allow the modulation of a desired target to be assessed [56]. Therefore, the identification of the protein target structure is the initial step of the SBDD. Once the target has been identified, it is necessary to obtain accurate structural information about it and its druggable binding sites. The main methods to get 3D structures of proteins are cryo-electron microscopy (EM), nuclear magnetic resonance (NMR) and X-ray crystallography [57-60]. All the resolved structures are deposited in databases such as the Protein Data Bank (PDB). In the cases where the target 3D structure has not been resolved yet, molecular modeling methods are employed to model the structure using as template a protein with at least $30 \%$ of amino acid sequence identity [61]. These comparative models usually lead to an increased error when attempting to study the receptor-ligand-binding affinity. However, in some cases (e.g., membrane proteins) it is the only alternative due to the lack of 3D structures [62-64].

Another critical issue is the identification of possible binding pockets in the target. Knowledge of protein-ligand-binding sites and their chemical environment contributes to improve the hit rate in virtual screening (VS) campaigns of chemical libraries and guide the lead optimization process to propose new potential drugs. It is especially useful to identify or design allosteric inhibitors. Different tools have been developed in the last decades for cavity search based on many different algorithms and machine-learning strategies using mainly geometric, energy-based, or probe-mapping probes [65]. For instance, Fpocket detects and identifies druggable pockets through the clustering of alpha spheres and Voronoi tessellation [66], scoring each pocket according to alpha sphere density, polarity or hydrophobic density.

As mentioned before, the main objective of this approach is to know the binding site(s) and the critical interactions between the target and a specific ligand in order to identify or design new ligands, with improved affinity and/or selectivity. Molecular docking is a powerful tool to achieve this goal. These methods have a wide variety of uses and applications, including structure-activity studies, hit identification, or lead optimization, providing binding hypotheses that facilitate predictions for multiple studies. Molecular docking is a useful tool to predict both structurally the most likely binding mode, and energetically the binding affinity of a small ligand onto the target. Mainly, it has been used to identify novel chemical probes and hits that can be optimized into lead molecules and drug candidates [26].

A very interesting computational tool to improve the drug search and to allow the use significant collections of compounds is virtual screening (VS). The goal of VS is to identify novel ligands that could bind the target of interest and predict a ranking of potential active ligands. To achieve this ranking of compounds, during the process besides the docking studies that in fact it is the last step different filters such as physicochemical properties, drug-like properties, and pharmacophore models are used, employing commercially available or in-house chemical libraries upon the structure of the target [26]. Another powerful tool is Molecular Dynamics simulations (MDs), which allow to simulate dynamic biological and chemical events at the atomic level. MDs have replaced the early view of proteins as relatively rigid structures by a dynamic model in which internal conformational changes under physiological conditions provide further information of the complete system [67]. 
In protein databases such as UniProt, PDB, EIBI, etc., several co-crystallized receptor-ligand complexes can be found, which allow study of the interactions between both players from a structural point of view. This information is beneficial for the development of novel molecules with therapeutic potential, using the SBDD and LBDD methods. In this sense, exciting results have been reported regarding the development of compounds for the treatment of different diseases, including NDD.

\section{Drug Design and Discovery Targeting NDD}

As stated, AD has a multifactorial nature, where multiple genetic and biological factors underlie the pathophysiology of this disease [68]. Nowadays, two neurological defects have been widely studied and described, cholinergic neuronal lost and amyloid- $\beta(A \beta)$ peptide misfolding and aggregation processed from the amyloid precursor protein (APP) [69]. Genetics of APP is also involved in the progression of the disease [70]. When APPs are processed by $\beta$ and $\gamma$-secretase form A $\beta 40$ and $A \beta 42$ peptides, which then undergo aggregation and oligomer formation and eventually cause formation of amyloids plaques [71,72]. About $95 \%$ cases of $\mathrm{AD}$ are sporadic, and older age, hypertension, diabetes, heart disease, and apolipoprotein E (ApoE) 4 allele polymorphism are considered as some of the key factors involved in the development of the disease [73]. Currently, there are several attractive targets for anti-AD drug design. Some of these targets already have FDA-approved inhibitors such as AChE (donepezil, rivastigmine, and galantamine [73]) and NMDA receptor (memantine [74]). Other targets for the design of effective and potent inhibitors are still under study. These include $\beta$ - and $\gamma$-secretase [75,76]; $\mathrm{BChE}$ (neuritic plaques and neurofibrillary tangles [77]); calcitonin gene-regulated peptide (Neurotransmitter) [78]; phosphodiesterase (hydrolysis of cGMP) [73]; mAchR (hyperphosphorylation of Tau protein) [79]; dopamine 2 receptor (A $\beta$ plaques) [80]; GABA-A receptor [81]; serotonin 5-HT6 receptor (improving cognition dysfunction, synaptic plasticity) [82]; among others. Here we review some of the most studied targets and how the design of bioactive compounds was done.

During the past decade, it has been shown that AChE also plays other non-hydrolytic functions in process such as synaptogenesis, which could be very interesting to modulate in AD. To identify allosteric sites that might modulate these non-hydrolytic functions, Roca et al. [83] used computational tools such as Fpocket to determine allosteric binding sites and VS coupled with MDs to identify new allosteric inhibitors by employing the MBC-library [84]. The identified compounds were also screened for in vitro inhibition of AChE, and three of them were observed to be active.

Camps et al. [85] using the crystal structure of AChE from Torpedo californica, in complex with the inhibitor tracrine (PDB code: $4 \mathrm{~W} 63$ ), developed the inhibitor huprine $X$, which inhibited human AChE in the $\mathrm{pM}$ range, exhibiting higher affinity than tacrine. Huprine $X$ now emerged as an alternative pharmacological ligand with better potency than the drugs used to date. Along similar lines, Rodríguez et al. [17] generated through green chemical synthesis a series of tetrahydroquinoline derivatives and evaluated its inhibitory potential against $\mathrm{AChE}$ and $\mathrm{BChE}$; the latter has also been found to be involved in the hydrolysis of the neurotransmitter acetylcholine in the brain of patients with AD. From these data and using the SBDD approach, and the crystal structures of AChE and BChE (PDB codes: 1E66 and 4BDS, respectively), the authors demonstrated through computational analysis using molecular docking and binding free energy calculations that two of the generated compounds showed inhibitory activity on the enzymes interacting with the reported active site of both enzymes. The authors indicated that the new potential cholinesterase inhibitors could be employed in the design of new drugs for $\mathrm{AD}$ treatments [17]. More recently, a series of 22 donepezil analogs, the most widely used AChE inhibitor prescribed for the treatment of $\mathrm{AD}$ [86], were developed. All the compounds exhibited a most potent inhibitory effect on AChE and BChE than donepezil [87]. Notably, five of the 22 molecules evaluated also showed an interesting inhibitory effect on the $\beta$-secretase enzyme (BACE1). As described above, BACE1 is involved in the accumulation of A $\beta$-peptide, [88]. The crystallographic structure of the BACE1 deposited in the PDB was used to study at an atomistic level-by using computational methods-how the newly designed ligands interact with BACE1. Based on the interaction modeling, 
the authors concluded that modifications of donepezil have the potential to yield better inhibitors than the parent compound [87]. Recently, Ponzoni et al. [8] have published a neural network model to predict the BACE1 inhibitory activity of any compound, employing machine-learning techniques.

The accumulation of $A \beta$-peptide has been correlated with the loss of the neuronal synapses associated with AD. This excess of $A \beta$-peptide is thought to be related with the suppression of the Wnt signaling pathway [89]. NOTUM enzyme is a carboxylesterase antagonist of Wnt pathway and Atkinson et al. [90], using the crystallographic data of NOTUM enzyme, developed the NOTUM inhibitor 2-phenoxyacetamide. The application of 2-phenoxyacetamide in cellular models of AD showed that the use of this inhibitor restores the Wnt pathway, positioning this inhibitor as a new drug with potential use for AD treatment and CNS disorders [90]. Other authors have used different approaches to design new drugs against non-conventional targets. For example, Gameiro et al. recently reported the first dual GSK3 $\beta$ inhibitor/Nrf2 inducer using a multitarget strategy for AD [91]. GSK3 $\beta$ is one of the most important kinases implicated un Tau hyperphosphorylation, and plays a pivotal role in the etiopathogenesis of $\mathrm{AD}$, whereas Nfr2 (predominantly cytoplasmic in neurons) is a transcriptional factor which promotes the synthesis of numerous antioxidant and anti-inflammatory enzymes [92].

Only a few well-studied therapeutic targets and drugs approved for the treatment of AD are available. In this review, we focus on some known targets that are implicated (directly and indirectly) in the mechanisms of $\mathrm{AD}$ pathology, as well as on the strategies that some authors have followed over the years to design new bioactive molecules. These targets are located in different regions of the brain and have diverse effects on different types of central functions such as synaptic plasticity, memory formation, neuronal apoptosis, oxidative stress, anti-inflammatory effects, cell survival, etc. Therefore, there is a latent need to explore these and new objectives in order to design effective and safe drugs for AD.

After AD, PD is the second most common NDD, with a prevalence of $2 \%$ among people over 65 year. The decrease in dopamine in the striatum along with the loss of cells in the substantia nigra is linked to the characteristic symptoms of rigidity, tremor and bradykinesia. One of the main pathophysiological characteristics of PD are Lewy bodies (large intracytoplasmic inclusions), a phenomenon that occurs in neurons of the substantia nigra that contain melanin [93-95]. In patients with PD, the Lewy bodies contain ubiquitin, $\alpha$-synuclein, and proteasomal subunits [93,95]. It has also been reported that mutations in the ubiquitin carboxy-terminal protein hydrolase may trigger familial PD [93,95]. It is considered that these mutations can lead to abnormalities in the proteolytic pathway and thus to the aggregation of proteins such as Lewy bodies [96].

Current treatments of PD are basically reduced to the use of levodopa (L-DOPA) [97]. This compound increases the level of the chemical messenger dopamine-which governs smooth, purposeful body movement-in the brain, which helps reduce many symptoms but does not stop the progression of the disease. L-DOPA in plasma is metabolized by catechol ortho methyltransferase (COMT) enzyme. Therefore, the development of compounds that peripherally inhibit COMT would improve the bioavailability of L-DOPA in the brain, reducing the end-of-dose deterioration symptoms and improving, in some cases, the control of motor symptoms in patients with PD [98]. Using CADD methods, the molecules Nebicapone [99] and BIA 3-335 [100] were developed as COMT high-affinity inhibitors. Both inhibitors were co-crystallized with rat COMT. The crystallographic structure of COMT with BIA 3-335 (PDB code: 1H1D) has been of particular pharmacological interest because it was the first structural data of a COMT-inhibitor complex [100].

There is still a significant set of proteins that have not been structurally resolved, are difficult to isolate, or even cases in which the crystallographic data are the private property of the pharmaceutical industry [101]. Therefore, it becomes necessary to model the protein of interest from the existing crystallographic data and sequences in databases. Homology (comparative) modeling is one of the most used computational techniques to predict the 3D structure of a protein at a low cost and less time [102]. Comparative modeling is based on two key experimental observations: (1) the protein 3D structure is determined by the primary structure, i.e., the aminoacidic sequence, and (2) the spatial 
protein structure evolves much slower than its sequence. Therefore, similar sequences adopt similar forms in space [103]. Thereby, homology modeling has become an ideal partner for drug design by the CADD approach (Figure 16).

Considering then that the identification of the molecular target is a prerequisite for the SBDD technique, and that homology modeling allows us to determine the 3D structure of the proteins with relative precision, the literature reports a series of successful studies to design drugs with therapeutic purposes using comparative modeling to predict key structural details of proteins involved in NDD [104-106]. For example, Lee and Kim [107] constructed a homology model of human COMT using the rat COMT X-ray crystal structure to perform ligand docking for designing anti-PD drugs. This in silico experiments, revealed nine inhibitory compounds that showed very favorable affinity energy, being therefore potential anti-PD drugs. Additionally, relevant information was inferred about the ligand-binding mechanisms, suggesting that Arg201 and Cys173 have a critical role in the inhibitors binding on human COMT.

Dhanavade et al. [108] studied through comparative modeling a cysteine protease present in Xhantomonas campestris the active site of which contains a set of residues practically identical to human cathepsin $\mathrm{B}$ enzyme (hCB), the activity of which contributes to the reduction of the $\beta$-amyloid peptide by proteolytic cleavage of A $\beta 1-42$, offering a protective role against AD [109]. The homology model was used in docking analysis with the $\beta$-amyloid peptide, demonstrating a favorable interaction between the Cys17 of the protease with the Lys16 of the peptide, evidencing a putative $\beta$-amyloid cleavage-site. The authors conclude that $X$. campestri cysteine protease could be used as a new molecular therapy for the treatment of $\mathrm{AD}$, in addition to being used as a reference structure for the development of clinically relevant drugs against $\mathrm{AD}[108]$.

As previously mentioned, Huntington disease (HD) is another NDD whose clinical characteristics are typically distinguished by chorea (abnormal, excessive, and involuntary hyperkinetic movement disorder), behavioral and psychiatric changes, and dementia [110]. The HD condition is caused by pathogenic CAG trinucleotide repeated expansion in exon 1 of huntingtin gene on chromosome $4[111,112]$. This genetic alteration causes an anomalous polyglutamine sequence near of $\mathrm{N}$-terminus of huntingtin protein (HTT), and this mutation has been related to the occurrence and severity of this neural disorder. $[113,114]$. The HTT protein is involved in several cellular mechanism due at their ubiquitous locations and multiple interaction sites with another proteins $[115,116]$. Specifically, HTT protein has roles in vesicular trafficking and recycling, cell division, regulation of transcription and embryonic development [117]. The abnormal polyglutamine leads a misfolding that triggers a cascade of pathogenic processes because an aberrant mRNA splicing, translation and fragment accumulation of toxic species from HTT proteolityc rupture $[118,119]$. This toxic species can form aggregates into inclusion bodies which are considered typical neuropathological traits of HD [118].

Despite identifying the genetic mutation involved in HD several years ago, nowadays only two drugs have been approved by FDA to treat this disease, tetrabenazine and deutetrabenazine, both belonging to the class of vesicular monoamine transporter Type 2 inhibitors, depleting presynaptic stores of dopamine (and other monoamines), leading to reduce the overstimulation of dopamine receptors observed in HD chorea [120]. However, even though TBZ is effective in managing chorea, its use in HD has been limited by side effects principally dose-related $[113,114,120]$. Unfortunately, there are not currently treatments that stop or delay the progression of neurological disorder observed in HD. In this sense, promissory efforts in the therapeutic development to treat HD have focused on intervention on specific targets of this disease such as HTT protein $[113,114]$.

Conforti et al. [121], performed an SBDD study to identify HTT analogs. The authors generated a REST homology model which, together with the crystallographic data of mSIN3a-PAH1, allowed simulating the biologically active repressor complex. In a first in silico approach using molecular docking, 94 molecules showed an inhibitory effect for the formation of the repressor complex, being C91 the compound with the highest repressive activity against RE1/NRSE [104]. Thereby, this work showed that the combination of dry and wet-lab based experiments could lead to the development of 
inhibitory compounds of REST activity, which could be very useful in HD treatment, and probably other central system nervous pathological conditions. Nowadays, emerging experimental therapies for disease modification also involve the targeting of lower levels of HTT as a novel putative strategy to face-off the pathological effects of this disease. This HTT-lowering therapy aims to reduce its synthesis blocking HTT-mRNA transcription, preventing post-transcriptional processing, fast mRNA degradation and modulation of HTT homeostasis, all with very promising results but with a necessary in-depth clinical evaluation to determine its safety and efficacy in HD patients [113,114].

In patients suffering multiple sclerosis disease, other NDD, demyelination is prominent in both white and gray matter. Chronic clinical deficits are known to result from acute or chronic injury to the myelin sheath and inadequate remyelination [122]. The 7-helix transmembrane G-coupled receptor family (GPCR) are a class of receptors activated by inflammatory molecules that act as a signal of damage, initiating cellular repair processes [123]. Specifically, GPR17 which has been recently proposed as a molecular target involved in multiple sclerosis, is an essential regulator of oligodendrocyte development and remyelination [123,124]. Eberini et al. [106], constructed a GPR17 homology model to evaluate an extensive set of possible agonists identified by virtual screening and later in vitro validation. The authors analyzed five activator ligands able to modulate the GPR17 activity with high efficiency as compared with endogenous ligands. This study was the first approach for the design of drugs aimed to the treatment of this demyelinating disease, an NDD without successful therapy until today.

Major depressive disorder (MDD) is a severe psychiatric condition $[125,126]$. Numerous clinical and preclinical studies indicate that a disturbance in central serotonin (5-hydroxytryptamine; 5-HT) activity is a crucial factor to trigger depressive symptoms $[127,128]$. The 5-HT3 receptor is a member of the ligand-activated ion channel family which has been identified as a potential target for the management of MDD [129-131]. Thus, Reeves et al. [132] constructed through homology modeling approach the 5-HT3 receptor extracellular loop, which contains the putative ligand-binding site using the ACh binding protein crystal as a template. In silico experiments allowed to identify and to confirm, the ligand-binding site and additionally showed that Asn128, Ser182, and Glu236 residues have a critical role in forming a hydrogen bond with agonists that could be involved in the channel opening. The 5-HT3 model and data obtained from this study were the starting point for the development of novel neuroactive drugs. In fact, in the last decade, the antagonism of 5-HT3 receptor has demonstrated successful antidepressant effects, and therapeutic potential against other disorders $[129,133]$.

\section{Challenges and Future Prospects}

The current pharmacological treatment of NDD does not alter the rate or extent of the neuronal cell loss. Therefore, there is an urgent need to develop drugs that can modify neurodegenerative processes in conditions such as $\mathrm{AD}$ and $\mathrm{PD}$, among others. These pathologies are a public health problem, affecting mainly the population over 60 years old. In this context, several questions emerge, including: What are the main reasons why effective pharmacological therapies have not been designed and developed to date? How can multidisciplinary lines be established to search and develop new proposals for the effective treatment of NDD? What kind of drugs need to be designed? These simple questions may relate to the methods through which drug discovery efforts have been carried out in the last century. Pharma industry and research centers were traditionally engaged in the development of compounds showing a single pharmacological profile with very high potency, like a "dart hitting the bullseye." In the case of conditions involving neurodegeneration-especially AD and PD, which have been categorized as multifactorial diseases, including geographic regions and incidence of mutation rates, as is the case of HD-this concept has not had the expected success for the development of efficacious treatment, as has been achieved, for instance, in the development of Ca-channels inhibitors used to treat arterial hypertension.

For this reason, an alternative strategy aiming to target multiple drug intervention points in complex diseases such as NDD, which can alter the disease progression, is currently being proposed. In this context, the promiscuity of a single molecule would take advantage of a simultaneous interaction 
with multiple therapeutic targets, all involved at different levels in a specific disease. This should lead to a higher efficacy upon the development and progression of the disease with a positive impact on the health of patients and their relatives. For instance, it is well documented that oxidative stress and chronic neuroinflammation are major pathological hallmarks of NDD, specially AD and PD. Thus, in our opinion, efforts in the design of drugs against NDD pathologies should focus on reducing these factors, rather than curing the disease when it is already in a very advanced stage. The research carried out in recent years has allowed us to observe that trying to cure AD or PD is not effective, and in short, the patients and their relatives are those who continue to suffer, without their quality of life improving. If efforts are focused on preventing the disease, studying which physiopathological events trigger the NDD and how to stop them, as well as researching on how to orient personalized medicine to identify and diagnose these diseases at very early stages, a paradigm shift could be made in the drug design targeting NDD. In this context, we believe that using several disciplinary approaches will allow us to obtain molecules with pharmacological and safety profiles better than those that are currently used.

Author Contributions: D.R. conceived the review. S.M.-N., L.P.-P., Y.A.R.N., L.S.-A., O.F.-D., W.G., N.E.C., M.R.-P., A.M., and D.R. conducted the literature review and wrote the manuscript.

Funding: This research was funded by FONDECYT (Fondo Nacional de Desarrollo Científico y Tecnológico) grant No. 1191133 to W.G.; and FONDECYT grant No 11180604 and CONICYT (Comisión Nacional de Investigación Científica y Tecnológica-Programa de Cooperación Internacional) grant No. REDES190074 to D.R.

Acknowledgments: The authors would also like to express their sincere gratitude to M.A. Claudia Daza Botero for assistance with manuscript editing. L.P.-P. thanks CONICYT for the doctoral scholarship No. 63130155. Y.A.R.N. thanks FONDECYT Post-Doctoral Fellowship No. 3190557. O.F.-D. thanks FONDECYT Post-Doctoral Fellowship No. 3170757. N.E.C. thanks MICINN (Ministerio de Ciencia, Innovación y Universidades) grant No. RTI2018-096100B-100. M.R.-P. thanks FONDECYT No. 1170662.

Conflicts of Interest: The authors declare no conflicts of interest.

\section{References}

1. United Nations Department of Economic and Social Affairs. World Population Ageing 2015; United Nations: New York, NY, USA, 2015; (ST/ESA/SER.A/390).

2. Wyss-Coray, T. Ageing, neurodegeneration and brain rejuvenation. Nature 2016, 539, 180-186. [CrossRef] [PubMed]

3. National Institute on Aging; National Institutes of Health. Global Health and Aging; World Health Organization: Geneva, Switzerland, 2011; Volume 1, pp. 1-32.

4. Bhat, S.; Kamal, M.; Yarla, N.; Ashraf, G. Synopsis on Managment Strategies for Neurodegenerative Disorders: Challenges from Bench to Bedside in Successful Drug Discovery and Development. Curr. Top. Med. Chem. 2017, 17, 1371-1378. [CrossRef] [PubMed]

5. Trippier, P.C.; Jansen Labby, K.; Hawker, D.D.; Mataka, J.J.; Silverman, R.B. Target- and Mechanism-Based Therapeutics for Neurodegenerative Diseases: Strength in Numbers. J. Med. Chem. 2013, 56, 3121-3147. [CrossRef] [PubMed]

6. Barnham, K.J.; Masters, C.L.; Bush, A.I. Neurodegenerative diseases and oxidative stress. Nat. Rev. Drug Discov. 2004, 3, 205-214. [CrossRef] [PubMed]

7. Burns, A.; Iliffe, S. Alzheimer's disease. BMJ 2009, 338, b158. [CrossRef]

8. Ponzoni, I.; Sebastián-Pérez, V.; Martínez, M.J.; Roca, C.; De la Cruz Pérez, C.; Cravero, F.; Vazquez, G.E.; Páez, J.A.; Díaz, M.F.; Campillo, N.E. QSAR Classification Models for Predicting the Activity of Inhibitors of Beta-Secretase (BACE1) Associated with Alzheimer's Disease. Sci. Rep. 2019, 9, 9102-9114. [CrossRef]

9. Hebert, L.E.; Scherr, P.A.; Bienias, J.L.; Bennett, D.A.; Evans, D.A. Alzheimer Disease in the US Population. Arch. Neurol. 2003, 60, 1119-1122. [CrossRef]

10. Sebastián-Pérez, V.; Martínez, M.J.; Gil, C.; Campillo, N.E.; Martínez, A.; Ponzoni, I. QSAR modelling for drug discovery: Predicting the activity of LRRK2 inhibitors for Parkinson's disease using cheminformatics approaches. In Advances in Intelligent Systems and Computing; Springer International Publishing: Berlin/Heidelberg, Germany, 2019; Volume 803, pp. 63-70.

11. Jankovic, J. Parkinson's disease: Clinical features and diagnosis. J. Neurol. Neurosurg. Psychiatry 2008, 79, 368-376. [CrossRef] 
12. Puginier, E.; Bharatiya, R.; Chagraoui, A.; Manem, J.; Cho, Y.H.; Garret, M.; De Deurwaerdère, P. Early neurochemical modifications of monoaminergic systems in the R6/1 mouse model of Huntington's disease. Neurochem. Int. 2019, 128, 186-195. [CrossRef]

13. Ribeiro, F.F.; Mendonca Junior, F.J.B.; Ghasemi, J.B.; Ishiki, H.M.; Scotti, M.T.; Scotti, L. Docking of Natural Products against Neurodegenerative Diseases: General Concepts. Comb. Chem. High Throughput Screen. 2018, 21, 152-160. [CrossRef]

14. Salloway, S.; Mintzer, J.; Weiner, M.F.; Cummings, J.L. Disease-Modifying therapies in Alzheimer's disease. Alzheimer's Dement 2008, 4, 65-79. [CrossRef] [PubMed]

15. Paul, S.M.; Mytelka, D.S.; Dunwiddie, C.T.; Persinger, C.C.; Munos, B.H.; Lindborg, S.R.; Schacht, A.L. How to improve R\&D productivity: The pharmaceutical industry's grand challenge. Nat. Rev. Drug Discov. 2010, 9, 203-214. [PubMed]

16. Sheldon, R.A. The e Factor: Fifteen years on. Green Chem. 2007, 9, 1273-1283. [CrossRef]

17. Rodríguez, Y.A.; Gutiérrez, M.; Ramírez, D.; Alzate-Morales, J.; Bernal, C.C.; Güiza, F.M.; Romero Bohórquez, A.R. Novel N -allyl/propargyl tetrahydroquinolines: Synthesis via Three-component Cationic Imino Diels-Alder Reaction, Binding Prediction, and Evaluation as Cholinesterase Inhibitors. Chem. Biol. Drug Des. 2016, 88, 498-510. [CrossRef] [PubMed]

18. Prent-Peñaloza, L.; De la Torre, A.F.; Velázquez-Libera, J.L.; Gutiérrez, M.; Caballero, J. Synthesis of diN-Substituted Glycyl-Phenylalanine Derivatives by Using Ugi Four Component Reaction and Their Potential as Acetylcholinesterase Inhibitors. Molecules 2019, 24, 189. [CrossRef] [PubMed]

19. Duarte, Y.; Fonseca, A.; Gutiérrez, M.; Adasme-Carreño, F.; Muñoz-Gutierrez, C.; Alzate-Morales, J.; Santana, L.; Uriarte, E.; Álvarez, R.; Matos, M.J. Novel Coumarin-Quinoline Hybrids: Design of Multitarget Compounds for Alzheimer's Disease. ChemistrySelect 2019, 4, 551-558. [CrossRef]

20. de Andrade, P.; Mantoani, S.P.; Gonçalves Nunes, P.S.; Magadán, C.R.; Pérez, C.; Xavier, D.J.; Hojo, E.T.S.; Campillo, N.E.; Martínez, A.; Carvalho, I. Highly potent and selective aryl-1,2,3-triazolyl benzylpiperidine inhibitors toward butyrylcholinesterase in Alzheimer's disease. Bioorg. Med. Chem. 2019, 27, 931-943. [CrossRef]

21. Chierrito, T.P.C.; Pedersoli-Mantoani, S.; Roca, C.; Sebastian-Pérez, V.; Martínez-Gonzalez, L.; Pérez, D.I.; Perez, C.; Canales, A.; Cañada, F.J.; Campillo, N.E.; et al. Chameleon-like behavior of indolylpiperidines in complex with cholinesterases targets: Potent butyrylcholinesterase inhibitors. Eur. J. Med. Chem. 2018, 145, 431-444. [CrossRef]

22. Gandini, A.; Bartolini, M.; Tedesco, D.; Martinez-Gonzalez, L.; Roca, C.; Campillo, N.E.; Zaldivar-Diez, J.; Perez, C.; Zuccheri, G.; Miti, A.; et al. Tau-Centric Multitarget Approach for Alzheimer's Disease: Development of First-in-Class Dual Glycogen Synthase Kinase $3 \beta$ and Tau-Aggregation Inhibitors. J. Med. Chem. 2018, 61, 7640-7656. [CrossRef]

23. Gawande, M.B.; Bonifácio, V.D.B.; Luque, R.; Branco, P.S.; Varma, R.S. Benign by design: Catalyst-free in-water, on-water green chemical methodologies in organic synthesis. Chem. Soc. Rev. 2013, 42, 5522. [CrossRef]

24. Cioc, R.C.; Ruijter, E.; Orru, R.V.A. Multicomponent reactions: Advanced tools for sustainable organic synthesis. Green Chem. 2014, 16, 2958-2975. [CrossRef]

25. Lim, H.J.; Myung, D.; Lee, I.Y.C.; Jung, M.H. Microwave-Assisted Synthesis of Benzimidazoles, Benzoxazoles, and Benzothiazoles from Resin-Bound Esters. J. Comb. Chem. 2008, 10, 501-503. [CrossRef] [PubMed]

26. Ramírez, D. Computational Methods Applied to Rational Drug Design. Open Med. Chem. J. 2016, 10, 7-20. [CrossRef] [PubMed]

27. Heck, S.; Dömling, A. A Versatile Multi-Component One-Pot Thiazole Synthesis. Synlett 2000, 2000, 424-426.

28. Ugi, I.; Dömling, A.; Hörl, W. Multicomponent reactions in organic chemistry. Endeavour 1994, 18, 115-122. [CrossRef]

29. LeVine, H. The challenge of inhibiting Abeta polymerization. Curr. Med. Chem. 2002, 9, 1121-1133. [CrossRef]

30. Lee, S.M.; Jeon, R. Synthesis of 6-[2-(benzoxazol-2-ylmethylamino)ethoxy]-1-alkyl-1H-indole-2-carboxylic acid and inhibitory activity on beta-amyloid aggregation. Arch. Pharm. Res. 2005, 28, 1219-1223. [CrossRef]

31. Spatz, J.H.; Bach, T.; Umkehrer, M.; Bardin, J.; Ross, G.; Burdack, C.; Kolb, J. Diversity oriented synthesis of benzoxazoles and benzothiazoles. Tetrahedron Lett. 2007, 48, 9030-9034. [CrossRef]

32. Armstrong, R.W.; Combs, A.P.; Tempest, P.A.; Brown, S.D.; Keating, T.A. Multiple-Component Condensation Strategies for Combinatorial Library Synthesis. Acc. Chem. Res. 1996, 29, 123-131. [CrossRef] 
33. Jangale, A.D.; Dalal, D.S. Highly Efficient, Combinatorial and Catalyst-Free Approach for the Synthesis of 2-Benzylidenehydrazono-3-phenyl-4-thiazolidinone-5-acetates in Ethanol. ChemistrySelect 2019, 4, 1323-1329. [CrossRef]

34. Karamthulla, S.; Pal, S.; Khan, M.N.; Choudhury, L.H. “On-water" synthesis of novel trisubstituted 1,3-thiazoles via microwave-assisted catalyst-free domino reactions. RSC Adv. 2014, 4, 37889-37899. [CrossRef]

35. Kushwaha, P.; Fatima, S.; Upadhyay, A.; Gupta, S.; Bhagwati, S.; Baghel, T.; Siddiqi, M.I.; Nazir, A.; Sashidhara, K.V. Synthesis, biological evaluation and molecular dynamic simulations of novel Benzofuran-tetrazole derivatives as potential agents against Alzheimer's disease. Bioorg. Med. Chem. Lett. 2019, 29, 66-72. [CrossRef] [PubMed]

36. Tang, X.; Zhu, S.; Ma, Y.; Wen, R.; Cen, L.; Gong, P.; Wang, J. A Simple and Efficient Synthesis of Highly Substituted Indeno[1,2-b]pyrrole and Acenaphtho[1,2-b]pyrrole Derivatives by Tandem Three-Component Reactions. Molecules 2018, 23, 3031. [CrossRef] [PubMed]

37. Scotti, L.; Scotti, M.T. Computer Aided Drug Design Studies in the Discovery of Secondary Metabolites Targeted Against Age-Related Neurodegenerative Diseases. Curr. Top. Med. Chem. 2015, 15, 2239-2252. [CrossRef]

38. Ghorbani-Vaghei, R.; Toghraei-Semiromi, Z.; Karimi-Nami, R. One-pot synthesis of 4H-chromene and dihydropyrano[3, 2-c]chromene derivatives in hydroalcoholic media. J. Braz. Chem. Soc. 2011, 22, 905-909. [CrossRef]

39. Mehrabi, H.; Kazemi-Mireki, M. CuO nanoparticles: An efficient and recyclable nanocatalyst for the rapid and green synthesis of 3,4-dihydropyrano[c]chromenes. Chin. Chem. Lett. 2011, 22, 1419-1422. [CrossRef]

40. Heravi, M.M.; Zakeri, M.; Mohammadi, N. Morpholine Catalyzed One-pot Multicomponent Synthesis of Compounds Containing Chromene Core in Water. Chin. J. Chem. 2011, 29, 1163-1166. [CrossRef]

41. Celik, F.; Unver, Y.; Barut, B.; Ozel, A.; Sancak, K. Synthesis, Characterization and Biological Activities of New Symmetric Bis-1,2,3-Triazoles with Click Chemistry. Med. Chem. 2018, 14, 230-241. [CrossRef]

42. Sciú, M.L.; Sebastián-Pérez, V.; Martinez-Gonzalez, L.; Benitez, R.; Perez, D.I.; Pérez, C.; Campillo, N.E.; Martinez, A.; Moyano, E.L. Computer-aided molecular design of pyrazolotriazines targeting glycogen synthase kinase 3. J. Enzym. Inhib. Med. Chem. 2019, 34, 87-96. [CrossRef]

43. Olesen, P.H.; Sørensen, A.R.; Ursø, B.; Kurtzhals, P.; Bowler, A.N.; Ehrbar, U.; Hansen, B.F. Synthesis and in Vitro Characterization of 1-(4-Aminofurazan-3-yl)-5-dialkylaminomethyl-1 $\mathrm{H}$-[1,2,3]triazole-4-carboxylic Acid Derivatives. A New Class of Selective GSK-3 Inhibitors. J. Med. Chem. 2003, 46, 3333-3341. [CrossRef]

44. El-Saghier, A.M.; Mohamed, M.A.; Abd-Allah, O.A.; Kadry, A.M.; Ibrahim, T.M.; Bekhit, A.A. Green synthesis, antileishmanial activity evaluation, and in silico studies of new amino acid-coupled 1,2,4-triazoles. Med. Chem. Res. 2019, 28, 169-181. [CrossRef]

45. Fereidoonnezhad, M.; Mostoufi, A.; Eskandari, M.; Zali, S.; Aliyan, F. Multitarget Drug Design, Molecular Docking and PLIF Studies of Novel Tacrine-Coumarin Hybrids for the Treatment of Alzheimer's Disease. Iran. J. Pharm. Res. 2018, 17, 1217-1228. [PubMed]

46. Zhang, H.Y. One-compound-multiple-targets strategy to combat Alzheimer's disease. FEBS Lett. 2005, 579, 5260-5264. [CrossRef] [PubMed]

47. Das, M.; Prakash, S.; Nayak, C.; Thangavel, N.; Singh, S.K.; Manisankar, P.; Devi, K.P. Dihydroactinidiolide, a natural product against A $325-35$ induced toxicity in Neuro2a cells: Synthesis, in silico and in vitro studies. Bioorg. Chem. 2018, 81, 340-349. [CrossRef]

48. Porcal, W.; Hernández, P.; González, M.; Ferreira, A.; Olea-Azar, C.; Cerecetto, H.; Castro, A. Heteroarylnitrones as Drugs for Neurodegenerative Diseases: Synthesis, Neuroprotective Properties, and Free Radical Scavenger Properties. J. Med. Chem. 2008, 51, 6150-6159. [CrossRef] [PubMed]

49. Chandra, N. Computational approaches for drug target identification in pathogenic diseases. Expert Opin. Drug Discov. 2011, 6, 975-979. [CrossRef]

50. Malathi, K.; Ramaiah, S. Bioinformatics approaches for new drug discovery: A review. Biotechnol. Genet. Eng. Rev. 2018, 34, 243-260. [CrossRef]

51. Liu, C.; Constantinides, P.P.; Li, Y. Research and development in drug innovation: Reflections from the 2013 bioeconomy conference in China, lessons learned and future perspectives. Acta Pharm. Sin. B 2014, 4, 112-119. [CrossRef] 
52. Sehgal, S.A. Pharmacoinformatics, Adaptive Evolution, and Elucidation of Six Novel Compounds for Schizophrenia Treatment by Targeting DAOA (G72) Isoforms. Biomed. Res. Int. 2017, 2017, 1-19. [CrossRef]

53. Sehgal, S.A.; Khattak, N.A.; Mir, A. Structural, phylogenetic and docking studies of D-amino acid oxidase activator (DAOA), a candidate schizophrenia gene. Biol. Med. Model. 2013, 10, 3-16. [CrossRef]

54. Yu, W.; MacKerell, A.D. Computer-Aided Drug Design Methods. In Methods in Molecular Biology; Humana Press: New York, NY, USA, 2017; Volume 1520, pp. 85-106.

55. Lounnas, V.; Ritschel, T.; Kelder, J.; McGuire, R.; Bywater, R.P.; Foloppe, N. Current progress in structure-based rational drug design marks a new mindset in drug discovery. Comput. Struct. Biotechnol. J. 2013, 5, e201302011. [CrossRef] [PubMed]

56. Schenone, M.; Dančík, V.; Wagner, B.K.; Clemons, P.A. Target identification and mechanism of action in chemical biology and drug discovery. Nat. Chem. Biol. 2013, 9, 232-240. [CrossRef] [PubMed]

57. Wang, H.-W.; Wang, J.-W. How cryo-electron microscopy and X-ray crystallography complement each other. Protein Sci. 2017, 26, 32-39. [CrossRef] [PubMed]

58. Rankin, N.J.; Preiss, D.; Welsh, P.; Burgess, K.E.V.; Nelson, S.M.; Lawlor, D.A.; Sattar, N. The emergence of proton nuclear magnetic resonance metabolomics in the cardiovascular arena as viewed from a clinical perspective. Atherosclerosis 2014, 237, 287-300. [CrossRef] [PubMed]

59. Carroni, M.; Saibil, H.R. Cryo electron microscopy to determine the structure of macromolecular complexes. Methods 2016, 95, 78-85. [CrossRef]

60. Callaway, E. The revolution will not be crystallized: A new method sweeps through structural biology. Nature 2015, 525, 172-174. [CrossRef]

61. Forrest, L.R.; Tang, C.L.; Honig, B. On the Accuracy of Homology Modeling and Sequence Alignment Methods Applied to Membrane Proteins. Biophys. J. 2006, 91, 508-517. [CrossRef]

62. Rinné, S.; Kiper, A.K.; Vowinkel, K.S.; Ramírez, D.; Schewe, M.; Bedoya, M.; Aser, D.; Gensler, I.; Netter, M.F.; Stansfeld, P.J.; et al. The molecular basis for an allosteric inhibition of $\mathrm{K}^{+}$-flux gating in $\mathrm{K}_{2 \mathrm{P}}$ channels. eLife 2019, 8, e39476. [CrossRef]

63. Bedoya, M.; Rinné, S.; Kiper, A.K.; Decher, N.; González, W.; Ramírez, D. TASK Channels Pharmacology: New Challenges in Drug Design. J. Med. Chem. 2019, 62, 10044-10058. [CrossRef]

64. Ramírez, D.; Concha, G.; Arévalo, B.; Prent-Peñaloza, L.; Zúñiga, L.; Kiper, A.K.; Rinné, S.; Reyes-Parada, M.; Decher, N.; González, W.; et al. Discovery of Novel TASK-3 Channel Blockers Using a Pharmacophore-Based Virtual Screening. Int. J. Mol. Sci. 2019, 20, 4014. [CrossRef]

65. Pérot, S.; Sperandio, O.; Miteva, M.A.; Camproux, A.-C.; Villoutreix, B.O. Druggable pockets and binding site centric chemical space: A paradigm shift in drug discovery. Drug Discov. Today 2010, 15, 656-667. [CrossRef] [PubMed]

66. Le Guilloux, V.; Schmidtke, P.; Tuffery, P. Fpocket: An open source platform for ligand pocket detection. BMC Bioinform. 2009, 10, 168-179. [CrossRef] [PubMed]

67. Durrant, J.D.; McCammon, J.A. Molecular dynamics simulations and drug discovery. BMC Biol. 2011, 9, 71-80. [CrossRef] [PubMed]

68. Talwar, P.; Sinha, J.; Grover, S.; Rawat, C.; Kushwaha, S.; Agarwal, R.; Taneja, V.; Kukreti, R. Dissecting Complex and Multifactorial Nature of Alzheimer's Disease Pathogenesis: A Clinical, Genomic, and Systems Biology Perspective. Mol. Neurobiol. 2016, 53, 4833-4864. [CrossRef] [PubMed]

69. Govoni, S.; Mura, E.; Preda, S.; Racchi, M.; Lanni, C.; Grilli, M.; Zappettini, S.; Salamone, A.; Olivero, G.; Pittaluga, A.; et al. Dangerous Liaisons between Beta-Amyloid and Cholinergic Neurotransmission. Curr. Pharm. Des. 2014, 20, 2525-2538. [CrossRef] [PubMed]

70. Hardy, J. The Amyloid Hypothesis of Alzheimer's Disease: Progress and Problems on the Road to Therapeutics. Science 2002, 297, 353-356. [CrossRef]

71. Butterfield, D.A.; Drake, J.; Pocernich, C.; Castegna, A. Evidence of oxidative damage in Alzheimer's disease brain: Central role for amyloid $\beta$-peptide. Trends Mol. Med. 2001, 7, 548-554. [CrossRef]

72. Butterfield, D.A.; Boyd-Kimball, D. The critical role of methionine 35 in Alzheimer's amyloid $\beta$-peptide (1-42)-induced oxidative stress and neurotoxicity. Biochim. Biophys. Acta 2005, 1703, 149-156. [CrossRef]

73. Chaudhary, A.; Maurya, P.K.; Yadav, B.S.; Singh, S.; Mani, A. Current Therapeutic Targets for Alzheimer's Disease. J. Biomed. 2018, 3, 74-84. [CrossRef] 
74. Danysz, W.; Parsons, C.G. The NMDA receptor antagonist memantine as a symptomatological and neuroprotective treatment for Alzheimer's disease: Preclinical evidence. Int. J. Geriatr. Psychiatry 2003, 18, S23-S32. [CrossRef]

75. Fukumoto, H.; Cheung, B.S.; Hyman, B.T.; Irizarry, M.C. $\beta$-Secretase Protein and Activity Are Increased in the Neocortex in Alzheimer Disease. Arch. Neurol. 2002, 59, 1381-1389. [CrossRef] [PubMed]

76. Yang, L.-B.; Lindholm, K.; Yan, R.; Citron, M.; Xia, W.; Yang, X.-L.; Beach, T.; Sue, L.; Wong, P.; Price, D.; et al. Elevated $\beta$-secretase expression and enzymatic activity detected in sporadic Alzheimer disease. Nat. Med. 2003, 9, 3-4. [CrossRef] [PubMed]

77. Perry, E.; Perry, R.; Blessed, G.; Tomlinson, B. Necropsy evidence of central cholinergic deficits in senile dementia. Lancet 1977, 309, 189. [CrossRef]

78. Park, P.; Sanderson, T.M.; Amici, M.; Choi, S.-L.; Bortolotto, Z.A.; Zhuo, M.; Kaang, B.-K.; Collingridge, G.L. Calcium-Permeable AMPA Receptors Mediate the Induction of the Protein Kinase A-Dependent Component of Long-Term Potentiation in the Hippocampus. J. Neurosci. 2016, 36, 622-631. [CrossRef] [PubMed]

79. Halliwell, J.V. Physiological mechanisms of cholinergic action in the hippocampus. Prog. Brain Res. 1990, 84, 255-272. [PubMed]

80. Blalock, E.M.; Geddes, J.W.; Chen, K.C.; Porter, N.M.; Markesbery, W.R.; Landfield, P.W. Incipient Alzheimer's disease: Microarray correlation analyses reveal major transcriptional and tumor suppressor responses. Proc. Natl. Acad. Sci. USA 2004, 101, 2173-2178. [CrossRef] [PubMed]

81. Castillo, P.E.; Chiu, C.Q.; Carroll, R.C. Long-term plasticity at inhibitory synapses. Curr. Opin. Neurobiol. 2011, 21, 328-338. [CrossRef]

82. Garcia-Alloza, M.; Hirst, W.D.; Chen, C.P.L.-H.; Lasheras, B.; Francis, P.T.; Ramírez, M.J. Differential Involvement of 5-HT1B/1D and 5-HT6 Receptors in Cognitive and Non-cognitive Symptoms in Alzheimer's Disease. Neuropsychopharmacology 2004, 29, 410-416. [CrossRef]

83. Roca, C.; Requena, C.; Sebastián-Pérez, V.; Malhotra, S.; Radoux, C.; Pérez, C.; Martinez, A.; Antonio Páez, J.; Blundell, T.L.; Campillo, N.E. Identification of new allosteric sites and modulators of AChE through computational and experimental tools. J. Enzym. Inhib. Med. Chem. 2018, 33, 1034-1047. [CrossRef]

84. Sebastián-Pérez, V.; Roca, C.; Awale, M.; Reymond, J.-L.; Martinez, A.; Gil, C.; Campillo, N.E. Medicinal and Biological Chemistry (MBC) Library: An Efficient Source of New Hits. J. Chem. Inf. Model. 2017, 57, 2143-2151. [CrossRef]

85. Camps, P.; Cusack, B.; Mallender, W.D.; El Achab, R.E.; Morral, J.; Muñoz-Torrero, D.; Rosenberry, T.L. Huprine $X$ is a novel high-affinity inhibitor of acetylcholinesterase that is of interest for treatment of Alzheimer's disease. Mol. Pharm. 2000, 57, 409-417.

86. Marco-Contelles, J.; Unzeta, M.; Bolea, I.; Esteban, G.; Ramsay, R.R.; Romero, A.; Martínez-Murillo, R.; Carreiras, M.C.; Ismaili, L. ASS234, as a New Multi-Target Directed Propargylamine for Alzheimer's Disease Therapy. Front. Neurosci. 2016, 10, 294-301. [CrossRef] [PubMed]

87. Green, K.; Fosso, M.; Garneau-Tsodikova, S. Multifunctional Donepezil Analogues as Cholinesterase and BACE1 Inhibitors. Molecules 2018, 23, 3252. [CrossRef] [PubMed]

88. O’Brien, R.J.; Wong, P.C. Amyloid Precursor Protein Processing and Alzheimer's Disease. Annu. Rev. Neurosci. 2011, 34, 185-204. [CrossRef] [PubMed]

89. Tapia-Rojas, C.; Inestrosa, N. Loss of canonical Wnt signaling is involved in the pathogenesis of Alzheimer's disease. Neural Regen. Res. 2018, 13, 1705-1710. [PubMed]

90. Atkinson, B.N.; Steadman, D.; Zhao, Y.; Sipthorp, J.; Vecchia, L.; Ruza, R.R.; Jeganathan, F.; Lines, G.; Frew, S.; Monaghan, A.; et al. Discovery of 2-phenoxyacetamides as Inhibitors of the Wnt-depalmitoleating enzyme NOTUM from an X-ray Fragment Screen. Medchemcomm 2019, 10, 1361-1369. [CrossRef]

91. Gameiro, I.; Michalska, P.; Tenti, G.; Cores, Á.; Buendia, I.; Rojo, A.I.; Georgakopoulos, N.D.; Hernández-Guijo, J.M.; Teresa Ramos, M.; Wells, G.; et al. Discovery of the first dual GSK3 $\beta$ inhibitor/Nrf2 inducer. A new multitarget therapeutic strategy for Alzheimer's disease. Sci. Rep. 2017, 7, 45701. [CrossRef]

92. Itoh, K.; Chiba, T.; Takahashi, S.; Ishii, T.; Igarashi, K.; Katoh, Y.; Oyake, T.; Hayashi, N.; Satoh, K.; Hatayama, I.; et al. An Nrf2/Small Maf Heterodimer Mediates the Induction of Phase II Detoxifying Enzyme Genes through Antioxidant Response Elements. Biochem. Biophys. Res. Commun. 1997, 236, 313-322. [CrossRef]

93. Ross, C.A.; Pickart, C.M. The ubiquitin-proteasome pathway in Parkinson's disease and other neurodegenerative diseases. Trends Cell Biol. 2004, 14, 703-711. [CrossRef] 
94. Polymeropoulos, M.H.; Lavedan, C.; Leroy, E.; Ide, S.E.; Dehejia, A.; Dutra, A.; Pike, B.; Root, H.; Rubenstein, J.; Boyer, R.; et al. Mutation in the -Synuclein Gene Identified in Families with Parkinson's Disease. Sci. Dly. 1997, 276, 2045-2047. [CrossRef]

95. Leroy, E.; Boyer, R.; Auburger, G.; Leube, B.; Ulm, G.; Mezey, E.; Harta, G.; Brownstein, M.J.; Jonnalagada, S.; Chernova, T.; et al. The ubiquitin pathway in Parkinson's disease. Nature 1998, 395, 451-452. [CrossRef] [PubMed]

96. Martin, J.B. Molecular Basis of the Neurodegenerative Disorders. N. Engl. J. Med. 1999, 340, 1970-1980. [CrossRef] [PubMed]

97. Mhyre, T.R.; Boyd, J.T.; Hamill, R.W.; Maguire-Zeiss, K.A. Parkinson's Disease. Subcell. Biochem. 2012, 65, 389-455. [PubMed]

98. Goldenberg, M.M. Medical management of Parkinson's disease. PT 2008, 33, 590-606.

99. Learmonth, D.A.; Vieira-Coelho, M.A.; Benes, J.; Alves, P.C.; Borges, N.; Freitas, A.P.; Soares-da-Silva, P. Synthesis of 1-(3,4-Dihydroxy-5-nitrophenyl)-2-phenyl-ethanone and Derivatives as Potent and Long-Acting Peripheral Inhibitors of Catechol- O -methyltransferase. J. Med. Chem. 2002, 45, 685-695. [CrossRef]

100. Learmonth, D.A.; Palma, P.N.; Vieira-Coelho, M.A.; Soares-da-Silva, P. Synthesis, Biological Evaluation, and Molecular Modeling Studies of a Novel, Peripherally Selective Inhibitor of Catechol- O -methyltransferase. J. Med. Chem. 2004, 47, 6207-6217. [CrossRef]

101. Schwede, T. Protein modeling: What happened to the "protein structure gap"? Structure 2013, 21, 1531-1540. [CrossRef]

102. Vyas, V.K.; Ukawala, R.D.; Ghate, M.; Chintha, C. Homology modeling a fast tool for drug discovery: Current perspectives. Indian J. Pharm. Sci. 2012, 74, 1-17. [CrossRef]

103. Chothia, C.; Lesk, A.M. The relation between the divergence of sequence and structure in proteins. EMBO J. 1986, 5, 823-826. [CrossRef]

104. Makhouri, F.R.; Ghasemi, J.B. In Silico Studies in Drug Research Against Neurodegenerative Diseases. Curr. Neuropharmacol. 2018, 16, 664-725. [CrossRef]

105. Cavasotto, C.N. Homology models in docking and high-throughput docking. Curr. Top. Med. Chem. 2011, 11, 1528-1534. [CrossRef] [PubMed]

106. Eberini, I.; Daniele, S.; Parravicini, C.; Sensi, C.; Trincavelli, M.L.; Martini, C.; Abbracchio, M.P. In silico identification of new ligands for GPR17: A promising therapeutic target for neurodegenerative diseases. J. Comput. Aided. Mol. Des. 2011, 25, 743-752. [CrossRef] [PubMed]

107. Lee, J.-Y.; Kim, Y.-M. Comparative Homology Modeling and Ligand Docking Study of Human Catechol-O-Methyltransferase for Antiparkinson Drug Design. Bull. Korean Chem. Soc. 2005, 26, 1695-1700.

108. Dhanavade, M.J.; Jalkute, C.B.; Barage, S.H.; Sonawane, K.D. Homology modeling, molecular docking and MD simulation studies to investigate role of cysteine protease from Xanthomonas campestris in degradation of A $\beta$ peptide. Comput. Biol. Med. 2013, 43, 2063-2070. [CrossRef] [PubMed]

109. Mueller-Steiner, S.; Zhou, Y.; Arai, H.; Roberson, E.D.; Sun, B.; Chen, J.; Wang, X.; Yu, G.; Esposito, L.; Mucke, L.; et al. Antiamyloidogenic and neuroprotective functions of cathepsin B: Implications for Alzheimer's disease. Neuron 2006, 51, 703-714. [CrossRef]

110. Roos, R.A. Huntington's disease: A clinical review. Orphanet J. Rare Dis. 2010, 5, 40-48. [CrossRef]

111. Walker, F.O. Huntington's disease. Lancet 2007, 369, 218-228. [CrossRef]

112. Andrew, S.E.; Paul Goldberg, Y.; Kremer, B.; Telenius, H.; Theilmann, J.; Adam, S.; Starr, E.; Squitieri, F.; Lin, B.; Kalchman, M.A.; et al. The relationship between trinucleotide (CAG) repeat length and clinical features of Huntington's disease. Nat. Genet. 1993, 4, 398-403. [CrossRef]

113. Bashir, H. Emerging therapies in Huntington's disease. Expert Rev. Neurother. 2019, 19, 983-995. [CrossRef]

114. Mestre, T.A. Recent advances in the therapeutic development for Huntington disease. Parkinsonism Relat. Disord. 2019, 59, 125-130. [CrossRef]

115. Cattaneo, E.; Zuccato, C.; Tartari, M. Normal huntingtin function: An alternative approach to Huntington's disease. Nat. Rev. Neurosci. 2005, 6, 919-930. [CrossRef] [PubMed]

116. Zuccato, C.; Valenza, M.; Cattaneo, E. Molecular Mechanisms and Potential Therapeutical Targets in Huntington's Disease. Physiol. Rev. 2010, 90, 905-981. [CrossRef] [PubMed]

117. Saudou, F.; Humbert, S. The Biology of Huntingtin. Neuron 2016, 89, 910-926. [CrossRef] [PubMed]

118. Arrasate, M.; Finkbeiner, S. Protein aggregates in Huntington's disease. Exp. Neurol. 2012, $238,1-11$. [CrossRef] 
119. Neueder, A.; Landles, C.; Ghosh, R.; Howland, D.; Myers, R.H.; Faull, R.L.M.; Tabrizi, S.J.; Bates, G.P. The pathogenic exon 1 HTT protein is produced by incomplete splicing in Huntington's disease patients. Sci. Rep. 2017, 7, 1307. [CrossRef]

120. Richard, A.; Frank, S. Deutetrabenazine in the treatment of Huntington's disease. Neurodegener. Dis. Manag. 2019, 9, 31-37. [CrossRef]

121. Conforti, P.; Zuccato, C.; Gaudenzi, G.; Ieraci, A.; Camnasio, S.; Buckley, N.J.; Mutti, C.; Cotelli, F.; Contini, A.; Cattaneo, E. Binding of the repressor complex REST-mSIN3b by small molecules restores neuronal gene transcription in Huntington's disease models. J. Neurochem. 2013, 127, 22-35. [CrossRef]

122. Nyamoya, S.; Leopold, P.; Becker, B.; Beyer, C.; Hustadt, F.; Schmitz, C.; Michel, A.; Kipp, M. G-Protein-Coupled Receptor Gpr17 Expression in Two Multiple Sclerosis Remyelination Models. Mol. Neurobiol. 2019, 56, 1109-1123. [CrossRef]

123. Mogha, A.; D’Rozario, M.; Monk, K.R. G Protein-Coupled Receptors in Myelinating Glia. Trends Pharm. Sci. 2016, 37, 977-987. [CrossRef]

124. Lu, C.; Dong, L.; Zhou, H.; Li, Q.; Huang, G.; Bai, S.J.; Liao, L. G-Protein-Coupled Receptor Gpr17 Regulates Oligodendrocyte Differentiation in Response to Lysolecithin-Induced Demyelination. Sci. Rep. 2018, 8, 4502. [CrossRef]

125. Kessler, R.C.; Berglund, P.; Demler, O.; Jin, R.; Koretz, D.; Merikangas, K.R.; Rush, A.J.; Walters, E.E.; Wang, P.S. The Epidemiology of Major Depressive Disorder. JAMA 2003, 289, 3095-3105. [CrossRef] [PubMed]

126. Ferrari, A.J.; Charlson, F.J.; Norman, R.E.; Patten, S.B.; Freedman, G.; Murray, C.J.L.; Vos, T.; Whiteford, H.A. Burden of Depressive Disorders by Country, Sex, Age, and Year: Findings from the Global Burden of Disease Study 2010. PLoS Med. 2013, 10, e1001547. [CrossRef] [PubMed]

127. Artigas, F. Serotonin receptors involved in antidepressant effects. Pharmacol. Ther. 2013, 137, $119-131$. [CrossRef] [PubMed]

128. Nautiyal, K.M.; Hen, R. Serotonin receptors in depression: From A to B. F1000Research 2017, 6, 123-135. [CrossRef] [PubMed]

129. Gupta, D.; Radhakrishnan, M.; Kurhe, Y. Ondansetron, a 5HT3 receptor antagonist reverses depression and anxiety-like behavior in streptozotocin-induced diabetic mice: Possible implication of serotonergic system. Eur. J. Pharm. 2014, 744, 59-66. [CrossRef]

130. Bétry, C.; Etiévant, A.; Oosterhof, C.; Ebert, B.; Sanchez, C.; Haddjeri, N. Role of 5-HT3 Receptors in the Antidepressant Response. Pharmaceuticals 2011, 4, 603-629. [CrossRef]

131. Rajkumar, R.; Mahesh, R. Review: The auspicious role of the 5-HT3 receptor in depression: A probable neuronal target? J. Psychopharmacol. 2010, 24, 455-469. [CrossRef]

132. Reeves, D.C.; Sayed, M.F.R.; Chau, P.-L.; Price, K.L.; Lummis, S.C.R. Prediction of 5-HT3 Receptor Agonist-Binding Residues Using Homology Modeling. Biophys. J. 2003, 84, 2338-2344. [CrossRef]

133. Price, K.L.; Lillestol, R.K.; Ulens, C.; Lummis, S.C.R. Palonosetron-5-HT 3 Receptor Interactions As Shown by a Binding Protein Cocrystal Structure. ACS Chem. Neurosci. 2016, 7, 1641-1646. [CrossRef] 